\title{
Biostratigraphic and petrological characteristics of Cretaceous-Paleogene sediments in the eastern Cuu Long delta
}

\author{
Mai Hoang Dam ${ }^{1}$ (]) $\cdot$ Vu Thi Tuyen ${ }^{1} \cdot$ Nguyen Tan Trieu $^{1} \cdot$ Nguyen Thi Tham $^{1}$
}

Received: 19 January 2021 / Accepted: 30 March 2021 / Published online: 12 April 2021

(c) The Author(s) 2021

\begin{abstract}
The basic structure of reservoir models is strongly affected by the stratigraphic interpretation and the properties of reservoir rock. The estimation of the volume of hydrocarbon accumulation will depend on the accuracy of predicting and distributing reservoir quality. Biostratigraphic and sedimentary petrologic results provide geological information to clarify the stratigraphy and properties of sedimentary rocks on the eastern margin of the Cuu Long delta plain trough. On the basis of stratigraphic correlation of the wells and studying the structures of the area, the deposition, thickness of sediments and the ability to correlate with prospect rocks on the southeastern Vietnam continental shelf were determined. The results have identified the basement rock of wells TC-1 and TC-2, which are Cretaceous metasandstones and were deposited in freshwater fluvial environments with high-energy conditions. The upper Paleogene sediments were overlaid directly on the Cretaceous basement rock in the TC- 2 well but were completely absent in the TC-1 well. The lithologic composition is mainly feldspathic litharenite sandstone, which is formed in freshwater fluvial and freshwater lacustrine environments. This study provides new data on stratigraphic column of the eastern Cuu Long delta plain. The data show that the age of the sedimentary basement rock is Cretaceous which has not been determined in previous studies. The findings of this study can help for better understanding of the geological development history and the completely stratigraphic column of the Cuu Long delta to correlate with objects that are hydrocarbon accumulation in Cuu Long sedimentary basin in order to improve efficiency in petroleum exploration activities.
\end{abstract}

Keywords Palynology $\cdot$ Biostratigraphy $\cdot$ Depositional environment $\cdot$ Cretaceous sediment $\cdot$ Paleogene sediment $\cdot$ Cuu Long delta

\section{Introduction}

In the early 1980 s, petroleum exploration in southern Vietnam was promoted both on the continental shelf and mainland in the Cuu Long delta. Paleontological and petrographic studies aimed at detailing borehole stratigraphic columns to clarify the geological structure of the area. These results have allowed the determination of the existence, characteristics and thickness of sediments and their relation to sedimentary basins that contain petroleum offshore of the continental shelf to assess and forecast the oil and gas prospects in the Cuu Long delta. In 1979, the Vietnam Oil and Gas General Department drilled two deep boreholes through

Mai Hoang Dam

dammh@vpi.pvn.vn

1 Analysis Laboratory Center, Vietnam Petroleum Institute, Hanoi, Vietnam the pre-Cenozoic basement rock east of the Cuu Long delta trough: TC-1 and CL-1.

According to the results of stratigraphic and petrographic studies (Huy 1981; Truong and Nghia 1981), the pre-Cenozoic basement rock of the CL-1 well is mainly granite and rhyolite, which are metamorphosed on a low grade, and the sediments covering them are late Paleogene-Neogene in age. The basement rock of the TC- 1 well is covered by Neogene sediments and its age has not been determined but is hypothesized to be a pre-Cenozoic sedimentary rock because they have not found evidence to determine the age of this sedimentary rock. However, in this study, we carried out detailed stratigraphic studies by the analysis of palynology, foraminifera and calcareous nannofossil. The results of the study show that palynomorph assemblages are found to be relatively abundant and are characteristic of the Cretaceous period and mainly deposited in the freshwater fluvial settings. This is also an interesting finding of this study. Since 
hydrocarbon accumulation was discovered in granitic basement rock in the Cuu Long basin, the basement rock in the Cuu Long delta was also considered an important rock to study in more detail. On the other hand, to re-evaluate the petroleum prospects in the Cuu Long delta, the TC- 2 well was drilled through Mesozoic sedimentary basement rock formations in the eastern Cuu Long delta in 2010. Hence, the authors selected two wells, TC-1 and TC-2, to perform this study (Fig. 1).

This study will provide the stratigraphic framework of the study region to clarify the sedimentary stratigraphic characteristics in the eastern Cuu Long delta and their relationship with sediments in the Cuu Long basin and the properties of the sedimentary rock for evaluating the reservoir quality.

\section{Geology of the Cuu Long delta}

The Cuu Long delta is located in southern Vietnam and is one of the largest deltas in Southeast Asia (Fig. 1). It received sediments from the Mekong River and its tributaries in the late Cenozoic due to the uplift and folding of the Earth's crust that was initiated approximately 50 million years ago by the collision of the Indian and Eurasian tectonic plates (Copley et al. 2010; Hiep and Dac 2018). The Cuu Long delta trough is filled by Tertiary sediments with complex horst and graben systems on the pre-Cenozoic basement rock (Sykes et al. 2011). Previous stratigraphic and tectonic study results of the inner basin show that the Cuu Long delta is limited by two different structural zones: the western and eastern margins. The western margin is the elevated structure of the Khorat-Natuna range and contains Devonian metamorphic shales, Carboniferous-Permian limestones and late Mesozoic terrestrial clastics. The eastern margin is the Mesozoic structure containing the Dong Nai basin and the central uplift. This structure is mainly composed of volcanic and continental sedimentary rocks that were formed on a heterogeneous base of gneissic metamorphic rocks, early Paleozoic green clay shale and Permian limestone that are deformed and metamorphosed around Mesozoic granite-granodiorite intrusions (Truong and Nghia 1981).

The study area is located onshore in the eastern Cuu Long delta. This field was discovered in 1979 by exploration wells named CL-1 and TC-1. Subsequently, another exploration well, TC-2, has been drilled to correspond to the southern structure of the CL-1 and TC-1 wells. Cretaceous-Paleogene sandstones are the focus of this study, which have continental depositional environments. The eastern area of the Cuu Long delta was formed during the Paleogene to Quaternary as a result of the opening of the East Sea and possibly the extrusion of the Indochina terrane during the Himalayan Orogenesis (Fyhn et al. 2009; Sykes et al. 2011) (Fig. 2). Its geological structure consists of two main troughs: the Vinh Chau trough (with an area of $2000 \mathrm{~km}^{2}$ ) and Ca Coi trough (with an area of $350 \mathrm{~km}^{2}$ ). They show rhombic morphology with steep faults that are bound narrowly and are relatively deep. The strike-slip faults that cut the grabens also exhibit "transtensional" and "transpressional" morphologies at releasing and restraining bends, respectively. The basement of the Vinh Chau and Ca Coi troughs is relatively shallow $(\sim 1.2 \mathrm{~km})$. Both troughs are believed to be
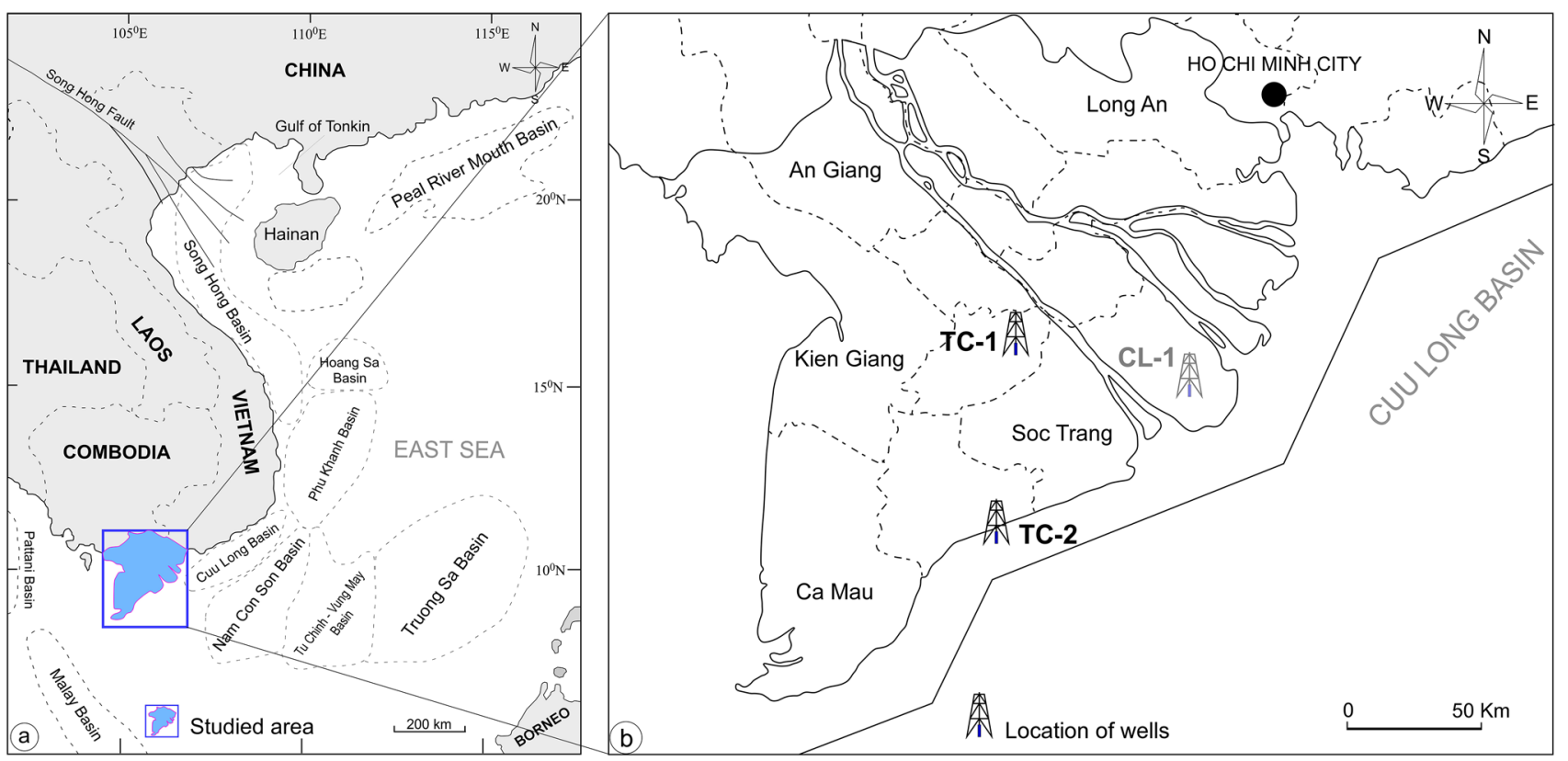

Fig. 1 a The study area and the sedimentary basins on the Vietnam continental shelf and adjacent areas (Nielsen et al. 2007). b Location of the wells in the Cuu Long delta (by Vietnam Oil and Gas Group 2019) 


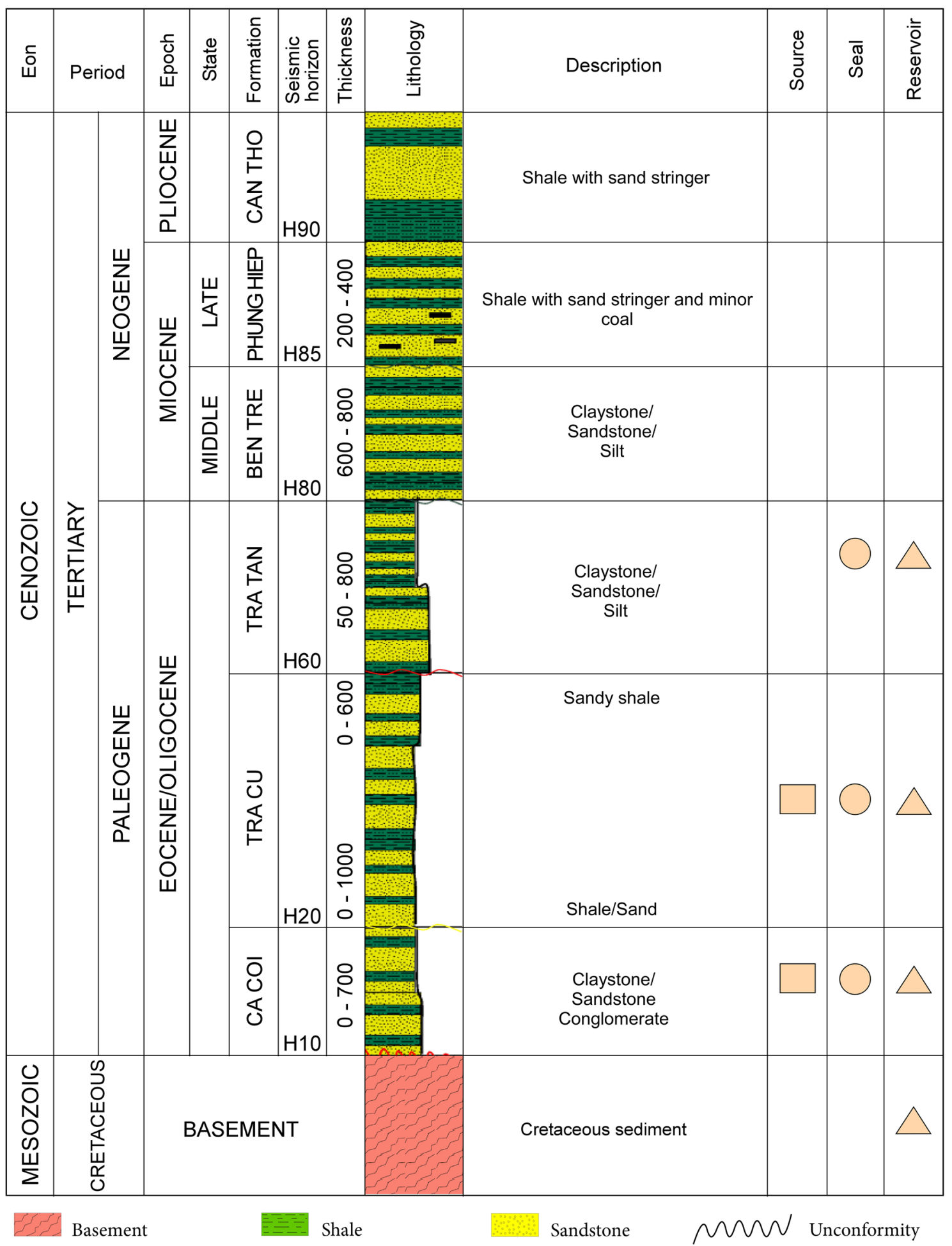

Fig. 2 Generalized stratigraphic column of the eastern trough of the Cuu Long delta modified after (Sykes et al. 2011)

analogues of the prolific Cuu Long basin, which is located approximately $150 \mathrm{~km}$ to the northeast of the Cuu Long delta (Fig. 1a). Stratigraphy of the Vinh Chau trough is provided by TC-2, stratigraphy of the Ca Coi trough is provided by
CL-1, and stratigraphy of the western margin of the Ca Coi trough is provided by TC- 1 . However, the $\mathrm{Ca}$ Coi trough is unclear because these wells, which are fully representative of the basin fill, were not drilled at a location where bright 
amplitudes are visible on seismic data (Sykes et al. 2011). The tectonic evolutionary history of the study area can be summarized as follows.

\section{Synrift stage (Eocene to Middle Miocene)}

The synrift section of the Vinh Chau trough can be subdivided into two synrift packages that are separated by a local unconformity. As mentioned earlier, this unconformity appears to relate to a renewed phase of rifting/extension. Depositionally, the two synrift packages appear to represent the sudden influx and gradual waning of sediments sourced from the adjacent footwall blocks. Each package has a strongly fining-upwards motif.

In the TC-1 well, the bottom of the first synrift phase, which overlies the weathered basement, comprises basal sandstone overlain by a section of largely mudstone (Fig. 3). This is in turn overlain by a massive sandstone package that exhibits a sharp base and an overall fining-upwards motif, suggesting a gradual decline in sediment supply. Palynofloras recovered from this sedimentary section indicate an Oligocene age ( $\mathrm{Tra} \mathrm{Cu}$ and Tra Tan formations) and suggest deposition in a predominantly freshwater alluvial setting.

The base of the second synrift phase is visible on seismic data as a marked unconformity (Fig. 3). In the TC-2 well, this unconformity is represented by the Oligocene-Miocene boundary, which reflects the return to the deposition of massive sandstones. The lower Ben Tre formation has a broadly fining-upwards motif exhibited in the well $\log$, which at the top grades conformably into mudstones at the base of the upper Ben Tre formation. Palynofloras recovered from the Ben Tre formation indicate a middle Miocene age and suggest deposition under predominantly fluvial conditions, although a transitional intertidal setting has been determined for the upper part of the Ben Tre formation.

\section{Postrift stage (Late Miocene to Present Day)}

The postrift succession is dominated by sandstones with minor interbedded mudstone. This succession has been subdivided into two subformations (Lower and Upper Phung Hiep) that are separated by an onlapping unconformity manifested on seismic data. The unconformity appears to be related to the transition from intertidal to fully marine deposition (neritic) and represents a marine flooding surface.

In the following sections, the materials and methods deployed during the study are described, followed by the results and discussion section and finally the summary and conclusions.

\section{Materials and methods}

The materials used for this study were obtained from the Vietnam Petroleum Institute (VPI) and the Vietnam Oil and Gas Group [Petrovietnam (PVN)]. A total of 29 ditch cuttings and 22 core samples were acquired from the TC- 1 and TC-2 wells. All samples were analysed at the Laboratory Analysis Center, Vietnam Petroleum Institute. In addition, the seismic and geophysical interpretation data and previous research results of adjacent areas were used to compare and correlate the stratigraphy with the wells in this study.



Fig. 3 Seismic transect across the pre-Cenozoic basement to the Pliocene of the Vinh Chau trough. The synrift stage contains two local unconformities, synrift 1 and synrift 2 , which coincide with the top of the basement and the top of the Oligocene strata, respectively 
The biostratigraphy method was performed by analysing parameters including calcareous nannofossils, foraminifera, palynology and palynofacies.

For calcareous nannofossils, a small portion of sediment was scraped onto a glass coverslip. A few drops of distilled water were added to make a thick sediment suspension using a flat-sided toothpick. The suspension was smeared thinly across the surface of the coverslip and dried on a hot plate for a few minutes at a temperature of approximately $60-70{ }^{\circ} \mathrm{C}$. All slides were analysed for calcareous nannofossils using a Zeiss Axio Imager A2 polarized light microscope with a magnification of 400X to scan for samples containing nannofossils. The biostratigraphic interpretation of the investigated sections is based on the calcareous nannofossil zonation of Martini (1971) and Backman et al. (2012). The nannofossil abundance and diversity were estimated by counting all species within 600 FOVs (fields of view) of the thin section.

For foraminifera, $30 \mathrm{~g}$ of uniform dried sediment samples were soaked in hydrogen peroxide $\left(30 \% \mathrm{H}_{2} \mathrm{O}_{2}\right)$ overnight and washed using a $63-\mu \mathrm{m}$ sieve. The retained material (with a grain size $>63 \mu \mathrm{m}$ ), which contained mostly fossil foraminiferal shells, was transferred into a $50 \mathrm{ml}$ beaker and then dried at $\sim 60^{\circ} \mathrm{C}$ for several hours. The dried fraction was then scattered into a standard tray for identification and separation of selected foraminiferal species under a stereoscopic microscope. The results of the analysis were recorded by counting all species that were obtained in the sample. The age and depositional environment of sediments were interpreted on the basis of the standard planktonic foraminifera schemes of Blow (1969) and Wade et al. (2011).

For palynology and palynofacies, $50 \mathrm{~g}$ of ditch-cut samples was washed, and then $10 \mathrm{~g}$ of claystone or $15 \mathrm{~g}$ of sandstone was taken for cleaning and crushing into 1-2-mmsized fragments. The samples were treated with an excess of $10 \%$ hydrochloric acid until effervescence to remove all carbonate components and allowed to stand for $24 \mathrm{~h}$. The suspensions were decanted very carefully, and then a $50 \%$ concentration of hydrofluoric acid was added to the residue overnight to remove siliceous material. Then, a heavy liquid separation in a zinc bromide solution was performed, and the specific gravity was 2.2 with a 5 -micron sieve. Residual organic matter was then oxidized by $\mathrm{HNO}_{3}$ for $20 \mathrm{~min}$. No oxidation treatments were performed to keep the organic matter intact for palynofacies investigation. The palynological slides were examined by using an Axio Imager A2 microscope and biological transmitted light microscope at magnifications of $20 \times$ to $100 \times$. The palynomorphs were identified by description and comparison with the palynozonal framework in Southeast Asia and adjacent regions by previous researchers such as Anderson $(1963,1964)$, Germeraad et al. (1968), Muller (1968), Morley (1977, 1991, 2000), Morley and Morley (2013), Anderson and Muller
(1975), Herngreen and Chlonova (1981), Hou (1981), Cole (1992) and Mao and Foong (2013). Full quantitative counts were made in each sample.

Palynofacies analysis is a powerful tool for characterizing a depositional system using the organic constituents of sedimentary rocks. Palynofacies is an important field within palynology that is useful to provide the interpretation of depositional environments (Tyson 1984, 1987, 1989, 1993, 1995). Each type of organic matter has its own physical and chemical characteristics related to depositional processes, energy conditions, sediment supplies and preservation, which may contribute to determining transport distances, with regard to the shape of the material (size/ sorting/roundness, etc.) (Batten 1996; Traverse 2007; Candel et al. 2013). Three main groups of morphological constituents can be recognized within particulate organic matter: palynomorphs, phytoclasts and amorphous organic matter (structureless) (Tyson 1993, 1995). The phytoclasts may be subdivided further into palynomacerals $1-4$ according to their buoyancy and degradation characteristics (Whitaker 1984; Van der Zwan 1990). The palynomorph constituents contain sporomorphs (including freshwater algae), marine dinocysts, acritarchs and foraminifera test linings. In certain depositional settings, bacterial biomass is believed to be preserved, referred to as structureless (sapropelic) organic matter (SOM) or amorphous organic matter (AOM). A separate count of $200 \mathrm{AOM}$ particles and phytoclasts was performed from each sample. The palynofacies analysis is based on the percentage frequency of different palynological organic matter (POM) constituents categorized by Tyson $(1987,1989$, 1993, 1995).

The sedimentological method was performed by thin section, scanning electronic microscopy (SEM) and X-ray diffraction (XRD) analysis to interpret the origin of sedimentary materials, depositional environment, stages of diagenesis (Folk 1974; Houghton 1980; Peter and Spearing 1982) and quality of the reservoir sand to evaluate the reserve for hydrocarbon accumulations.

Thin sections were studied under polarized microscopy to describe the mineral composition, texture and rock classification. The determination of mineral composition and visible porosity was performed by modal analysis, which involved counting 300 points in each thin section (van der Plas and Tobi 1965; Solomon and Green 1966). The textural study included the mean grain size, grain sorting, roundness and grain contacts (Folk and Ward 1957; Pettijohn 1975). The sandstone was classified based on Folk's classification (1974).

Scanning electron microscopy analysis reveals the morphologies of authigenic minerals and pore spaces and generates framework grains in 3D view at a high magnification. Furthermore, SEM analysis also aids in identifying the texture and fabric of sedimentary rock and

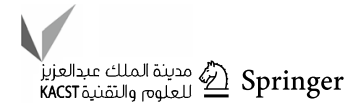


estimating the degree of post-depositional alteration and post-magmatic alteration. SEM analysis was carried out on a JEOL instrument (model JSM-5600LV). An energydispersive electron microbeam (EDX) (Oxford-model ISIS 310 ) is attached to correctly affirm authigenic minerals via chemical element spectra (Welton 2003; Phuong 2010; Dao 2010).

The XRD analysis for the clay fraction was run from $4^{\circ} 2 \theta$ to $30^{\circ} 2 \theta$ to determine the composition and relative percentage of clay minerals. Whole-rock analysis was carried out using approximately $1 \mathrm{~g}$ of sample that was ground by a micronising mill; the powder sample was then packed into a plastic sample holder and run from $3^{\circ} 2 \theta$ to $50^{\circ} 2 \theta$ (Hardy and Tucker 1988; Phuong 2010; Dao 2010). These analyses were carried out on the D8-Advance automatic system and set up at $40 \mathrm{~mA}$ and $40 \mathrm{kV}$ using $\mathrm{Cu}-\mathrm{K} \alpha$ radiation with a Ni filter, a step size of 0.010 degrees and a time scale of $0.2 \mathrm{~s}$. Four steps were included as follows:

The clay mount was dried at room temperature and humidity.

After ethylene glycol solvation for $24 \mathrm{~h}$ at $50-60^{\circ} \mathrm{C}$, swelling clays were detected.

Immediately following, it was heated to $300{ }^{\circ} \mathrm{C}$ for 30 mins. This step causes illite-smectite and smectite to coincide at 10 angstroms.

After heating to $550^{\circ} \mathrm{C}$ for one and a half hours, kaolinite collapses, and the brucite layer collapses within chlorite.

\section{Results and discussion}

\section{Biostratigraphic and petrographic characteristics of Cretaceous sediments}

The age of Cretaceous sediment of the TC- 1 and TC- 2 wells was identified by palynology assemblages. Its lithological composition is mainly arkosic sandstone, which is slightly metamorphosed in the TC-2 well, and silicate schist, which contains lime mudstone in the TC-1 well (Huy 1981). The paleoenvironmental interpretations presented in this section mainly depend on the semiquantitative palynofacies characteristics of selected constituents of the palynological matter, which are known to have paleoenvironmental significance. The changes in the palynofacies composition in sedimentary sections and the AOM-palynomorph-phytoclast ternary plot (Tyson 1989, 1993, 1995) reveal palynofacies types of this investigation.

\section{Biostratigraphic characteristics}

Similar to the TC-2 well, calcareous nannofossils and foraminifera are not found, suggesting that the sediment was not dominated by a marine depositional environment. The palynomorph recovered is not abundant but is characterized by the presence of the freshwater spore taxa Biretispotites eneabbaensis, Concavissimissporites crassarus, Cyathiidites punctatus, Klukisporites scaberi, Osmundacidites wellmanii, Osmundacidites senectus, Retitriletes spp.,

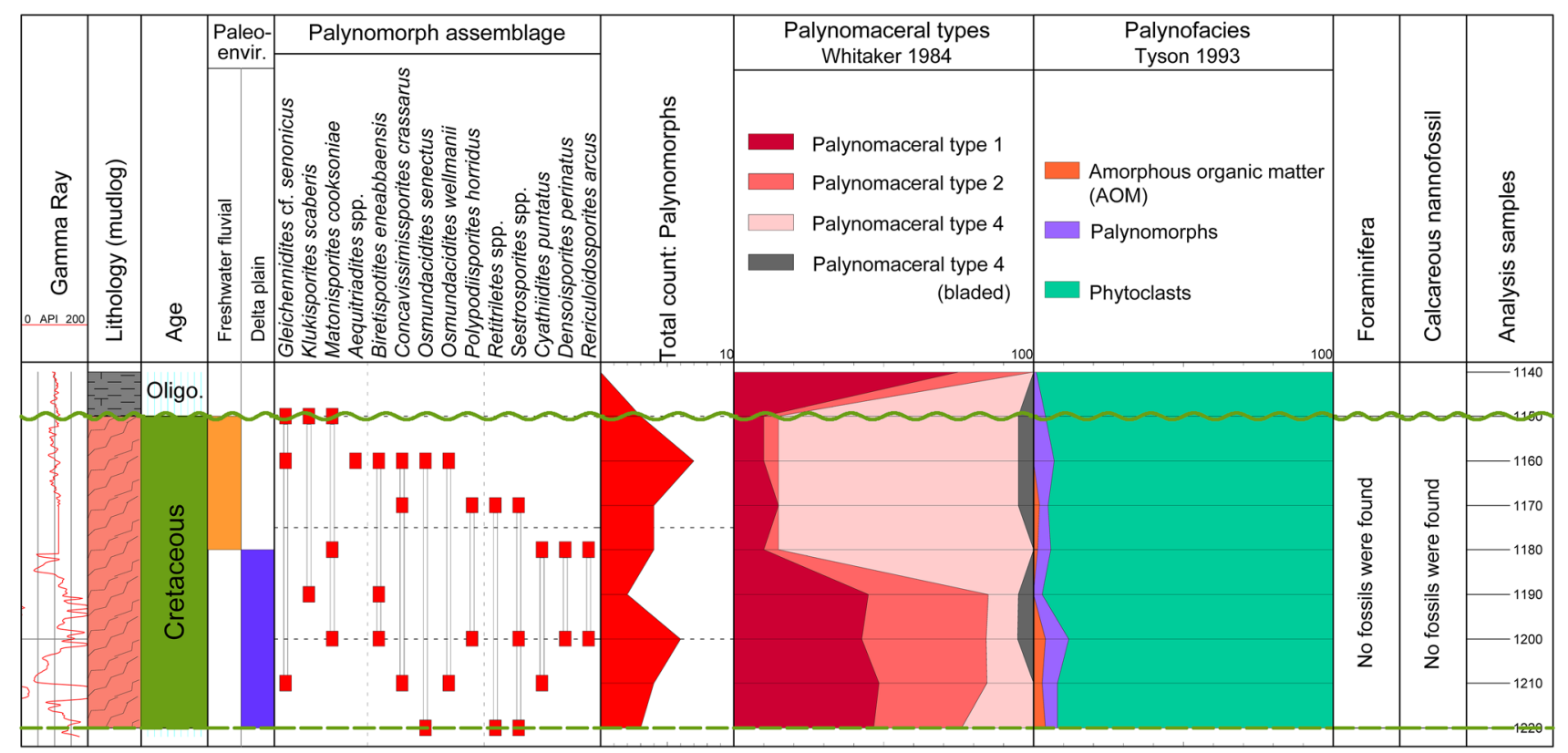

Fig. 4 Distribution chart of palynomorphs and palynofacies in Cretaceous sediments of the TC-2 well 
Reticuloidosporites arcus and Sestrosporites spp. (Fig. 4). These spore assemblages have been found in freshwater sediments and commonly occur in Cretaceous sediments, which are well known in southern Vietnam (Wantoro et al. 2005; Quang 2005, 2006), Malaysia (Muller 1968) and Australia (Helby et al. 1987; Burger 1996). The common morphological constituent of particulate organic matter is phytoclasts (92-98\%), which can be divided into two palynofacies types.

Palynofacies 1 (interval 1150-1180 m) is dominated by palynomaceral type 4 (approximately 90\%), which consists of black or almost black equidimensional or blade-shaped material that is usually uniformly opaque and structureless, remaining palynomaceral types 1 and 2 and no marine palynomorph (Fig. 5). Palynomaceral type 4 includes compressed humic gels, charcoal and geothermally fusinized material and is highly buoyant, indicating that the sediment was deposited in freshwater fluvial environments with highenergy conditions (Fig. 4). Palynofacies $2(1180-1220 \mathrm{~m}$ ) is characterized by terrestrial elements (95-97\%) with subsidiary AOM (3\%) and no marine palynomorphs. The phytoclast content shows a widespread dominance of palynomaceral type 1 (approximately 45\%), which consists of orange-brown or dark brown structured or structureless material, and palynomaceral type 2 (approximately $45 \%$ ), which includes brown-orange structured material of irregular shape (Fig. 4). The buoyancy and variable level of palynomaceral type 2 are considered to be higher than those of palynomaceral type 1, so the sediments were deposited in a delta plain environment with moderate energy conditions.

In the TC-1 well, no calcareous nannofossils or foraminifera were found in this section. Therefore, the palynology study method is the primary method to determine the age of sediments in this interval. The analysis indicated the existence of a characteristic freshwater palynology assemblage for an age that is not younger than the Cretaceous period from 857.00 to $1180.00 \mathrm{~m}$ in the samples: Biretisporites eneabbensis, Sestrosporites spp., Densoisporites perinatus, Matonisporites cooksoniae, Polypodiisporites horridus, Concavissimisporites crassatus, Contignisporites glebulentus, Contignisporites crenatus, Osmundacidites wellmanii, Osmundacidites senectus, Aequitriadites spp., Gleichennidites $\mathrm{cf}$ senonicus, Verrutricolpites spp., Aratrisporites parvispopinosus, Klukisporites scaberis and Cycadopites spp. (Figs. 6 and 7). According to Crepet (1983), Pellmyr (1992) and Mai (2016) angiosperm fossils are the oldest fossils recorded in the Early Cretaceous epoch (130-125 Ma). The presence of Verrutricolpites pollen was found in the core samples at $857 \mathrm{~m}, 935 \mathrm{~m}$ and $1187 \mathrm{~m}$, indicating that the age of the sedimentary rock in this section is not older than that of the Cretaceous period. The particulate component is composed of phytoclasts (over 95\%), which are dominated by palynomaceral type 4 (avg. 70\%), remaining palynomaceral types 1 and 2 (avg. 30\%) and freshwater palynomorphs (Fig. 7). It is characteristic of palynofacies 1 (TC-2 well), which indicates that the sediments were deposited in a freshwater fluvial environment with high-energy conditions. Remarkably, the presence of Dinoflagellate cyst undiff. at $1146 \mathrm{~m}$ and $1187 \mathrm{~m}$ in the samples indicate that there is a change in the depositional environment from freshwater fluvial to brackish water or coastal plains.

\section{Petrographic characteristics}

In the TC-2 well, the petrographic composition includes predominantly metasandstone (35-60\%) with small amounts of claystone $(5 \%)$, calcareous claystone $(5 \%)$, siltstone (5-10\%), carbonate (7-10\%), tuff debris (25\%) and volcanics (5-35\%) (Fig. 8). Metasandstone is classified as arkose and
Fig. 5 Photograph representing the recorded palynofacies in the TC-2 well. 1 Palynofacies showing high dominance of phytoclast debris and scattered fragmented AOM in sample 1170 m. 2-3 Palynofacies dominated by black wood, which is palynomaceral type 4 (PM4: opaque and bladed) in sample $1160 \mathrm{~m}$

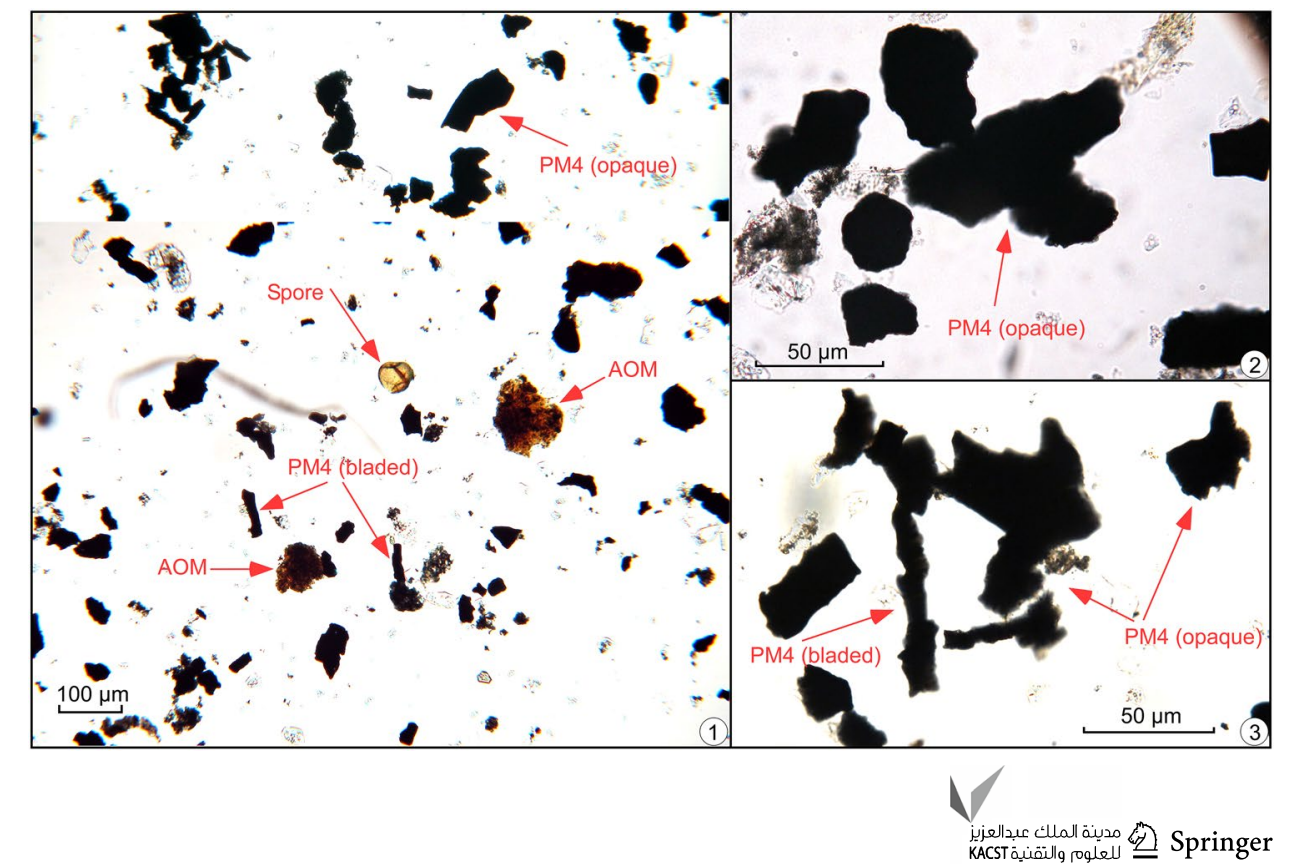




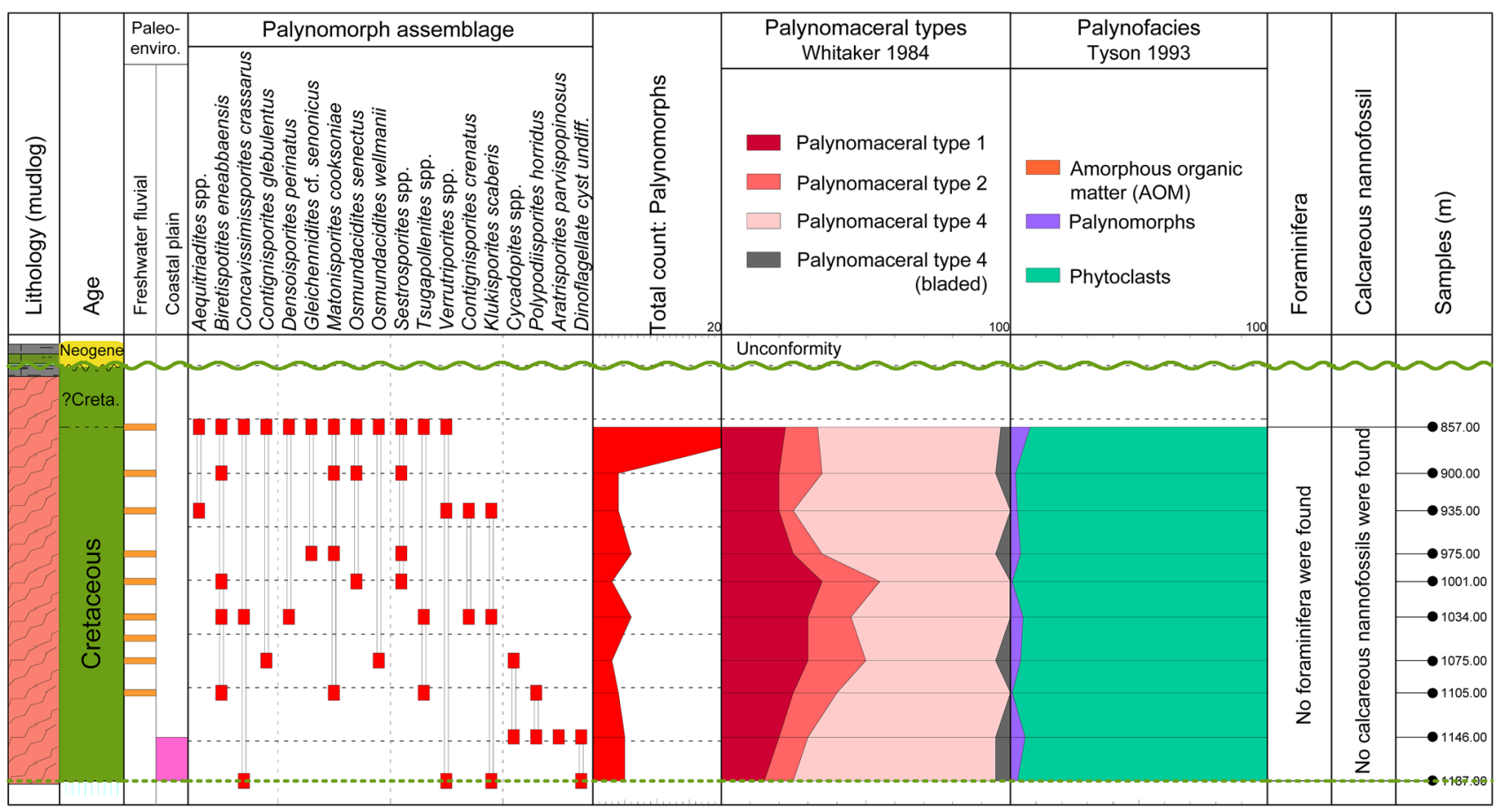

Fig. 6 Distribution chart of palynomorphs and palynofacies in Cretaceous sediments of the TC-1 well

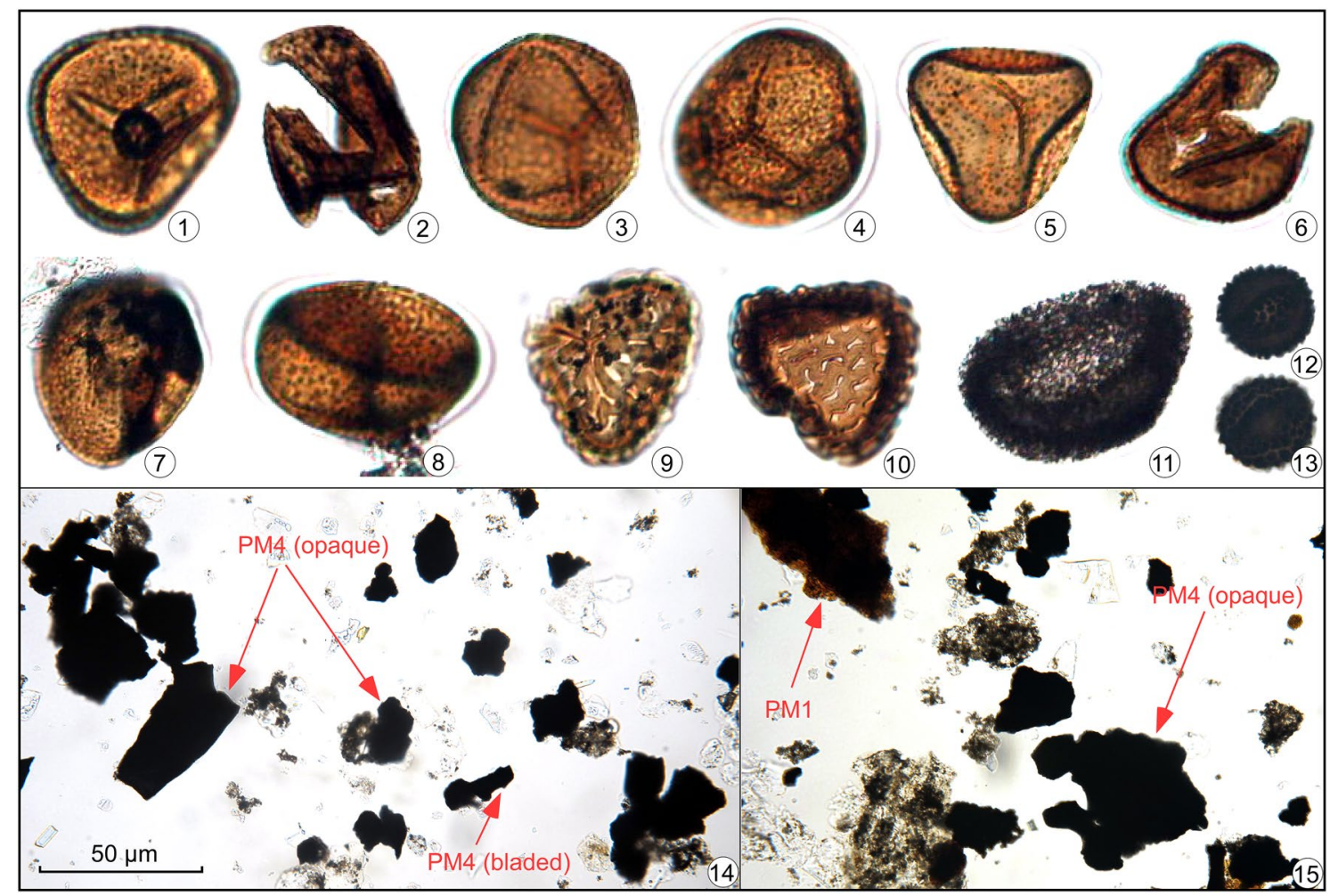

Fig. 7 1-13 Palynomorph assemblage of the Cretaceous sediment in the TC-1 well. 1 Matonisporites cooksoniae, 2 Concavissimisporites crassatus, 3 Aequitriradites sp., 4 Osmundacidites wellmanii, 5 Gleichennidites cf. senonicus, 6 Biretisporites $\mathrm{cf}$. eneabbaensis, 7 Contignisporites glebulentus, 8 Contignisporites crenatus, 9 Osmun- dacidites cf. senectus, 10 Sestrosporites sp., 11 Tsugapollenites sp., 12-13 Verrutricolpites spp., 14-15 Palynofacies dominated by palynomaceral type 4 (PM4: opaque and some bladed) and sparse palynomaceral type 1 (PM1). Scale bar is $50 \mu \mathrm{m}$ 

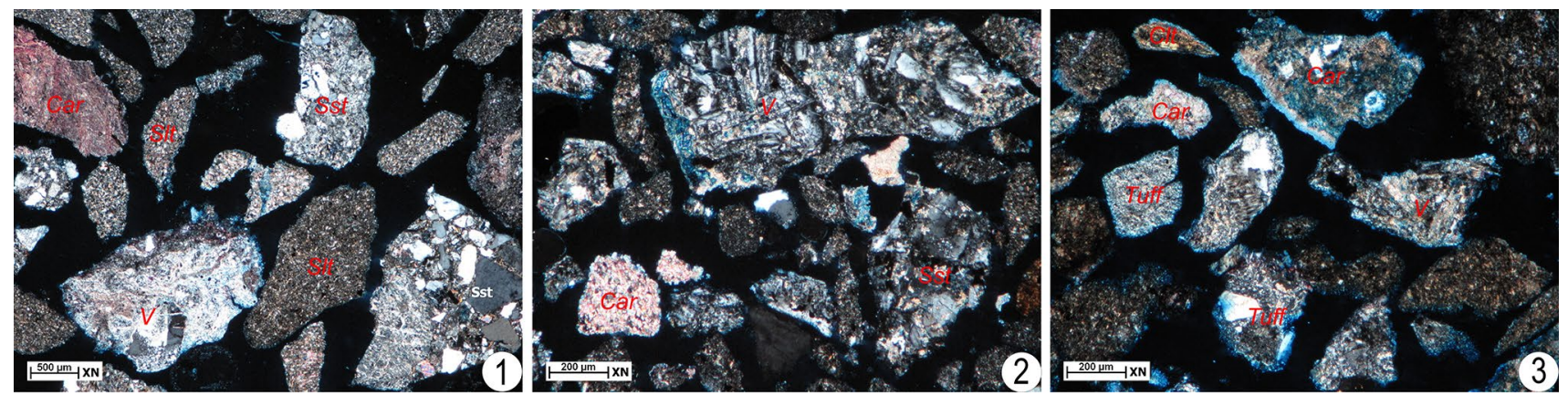

Fig. 8 Composition of Cretaceous metasandstone from ditch cuttings in the TC-2 well. 1 Depth interval $1175-1180 \mathrm{~m}$; 2 depth interval 1185-1190 m; 3 depth interval 1195-1200 m. Composition of the ditch cuttings includes metasandstone (Sst), claystone (Clt), siltstone (Slt), volcanic (V), carbonate (Car) and tuff

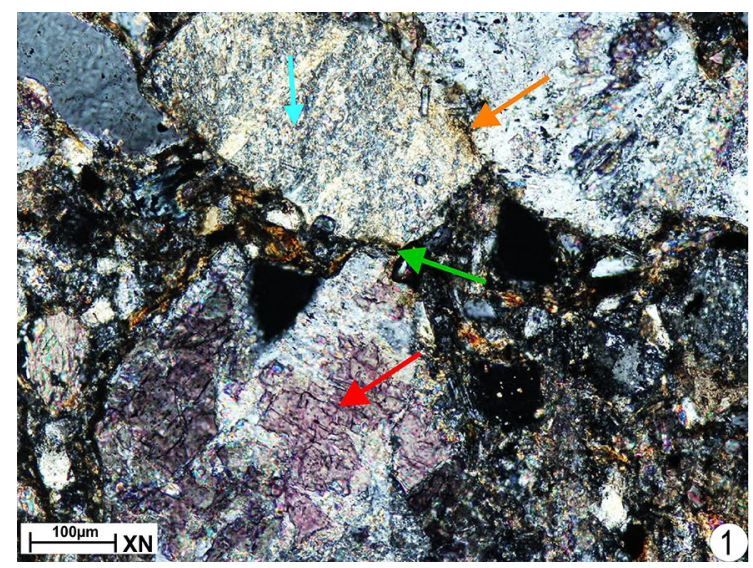

Fig. 9 Thin section photograph of Cretaceous metasandstone in the TC-2 well. 1 Depth interval 1175-1180 m. Feldspar grains have been dissolved and replaced by clay minerals (turquoise arrow) and calcite

has been strongly altered with medium grain size and poor sorting. Detrital grains are mainly angular and subangular to subrounded. The rock has been moderately compacted with point-to-point and long grain contacts (Fig. 9a).

Detrital grains include predominantly (Fig. 10) quartz with mostly monocrystalline $(31.8-38.2 \%)$ and rarely polycrystalline grains. Feldspar grains are present in medium amounts, such as K-feldspar (18.8-23.8\%) and small amounts of plagioclase (2.6-7.8\%), which have been replaced by calcite or clay minerals (Fig. 9a). Mica is present in small amounts $(4.4-5.2 \%)$ as biotite that has been slightly chloritized, and muscovite is still fresh. A small proportion of other rock fragments $(0.4-3.2 \%)$ consist of volcanic, granite, sedimentary fragments (chert, carbonate) and metamorphic fragments (schist, quartzite). Accessory minerals include apatite, zircon, epidote and rutile, which are sporadically present in very small amounts. Cement and authigenic minerals are present in large amounts and are mostly calcite (8.0-12.0\%), chlorite (2.6-3.6\%), opaque minerals $(0.6-1.6 \%)$ and other clay



(red arrow). Point-to-point grain contact (green arrow) and long grain contact (orange arrow); 2 depth interval 1185-1190 m, porosity filled by calcite cement (pink arrows)

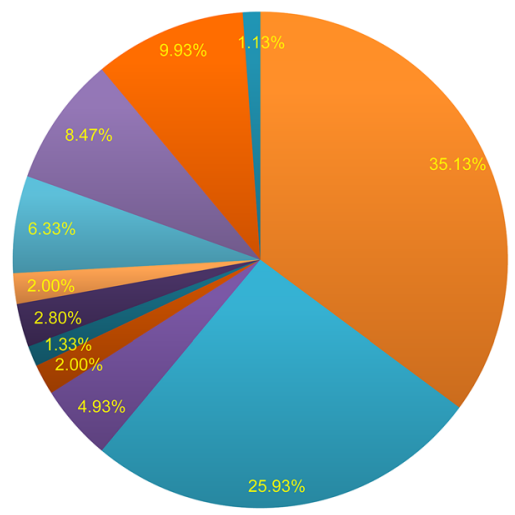

—Quartz

- Granite rock fragments


- Mica

Metamorphic rock fragments Matrix

— Authigenic carbonate minerals — Opaque minerals

Sedimentary rock fragment
Authigenic clay minerals

- Accessory minerals

Fig. 10 Detrital grain composition (\%) of metasandstone in the TC-2 well

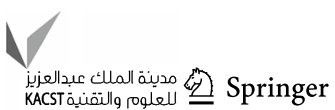




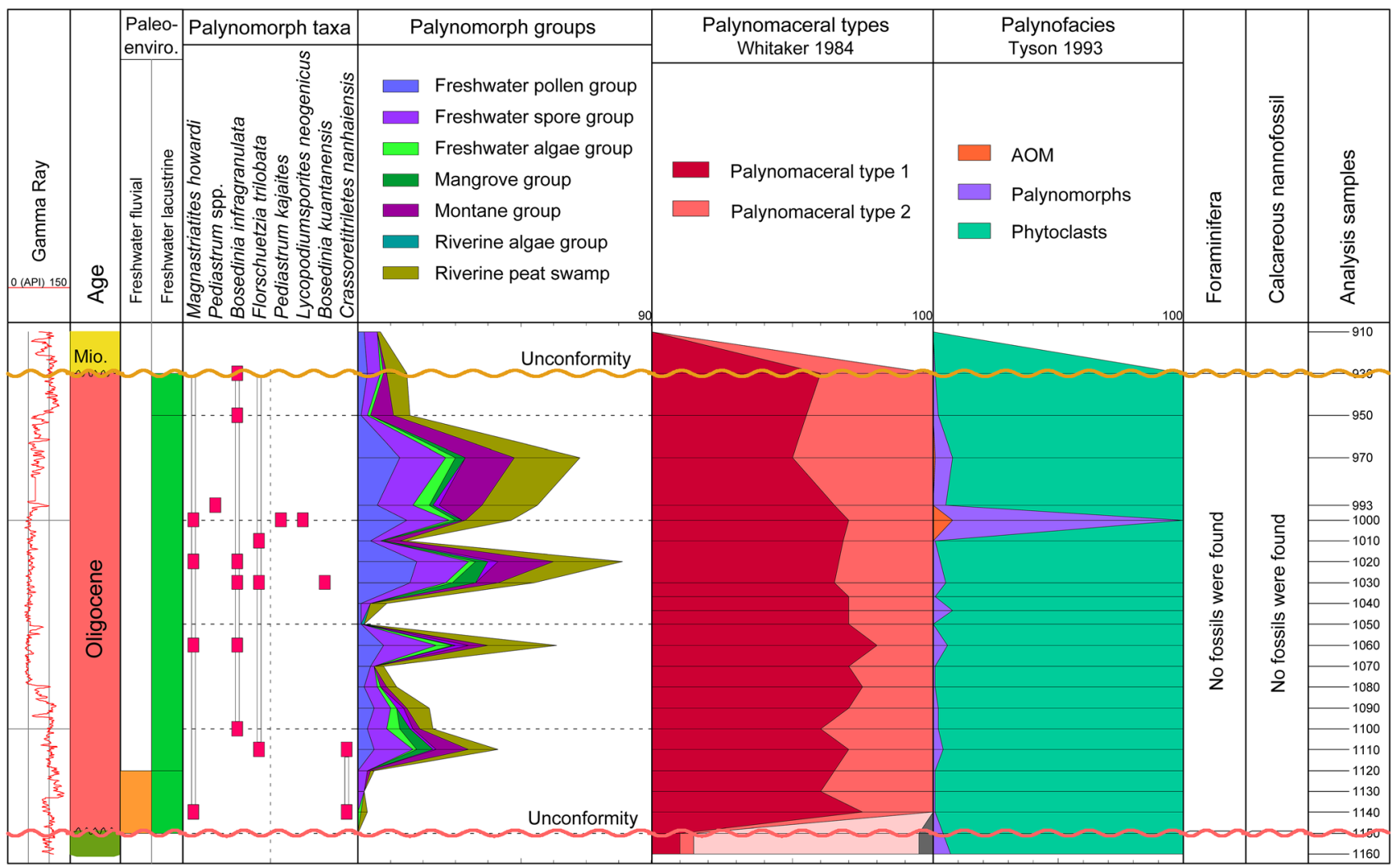

Fig. 11 Distribution chart of palynomorphs and palynofacies in Oligocene sediments of the TC-2 well

minerals (4.6-6.0\%). The visible porosity of all sandstones is damaged by compaction and cement phases, especially authigenic calcite minerals, quartz overgrowths and other authigenic minerals (Fig. 9b).

The whole-rock XRD analysis results indicate that clay minerals contain high levels (55.1-63.9\%), followed by quartz (23.2-34.2\%), K-feldspar (3.3-4.4\%) and plagioclase (7.5-9.3\%).

In general, arkose sandstones have been strongly altered. Based on the petrographic composition (arkose sandstone), framework grains, rock textures [including medium grain size, poor sorting and grain shape (angular, subangular to subrounded)] and detrital matrix, the sandstones have mature textures and minerals. As a result, the rock-forming sediments were transported within a distance that was nearby the original areas, and sands could have been frequently subjected to moderately high-energy flows and quickly deposited in alluvial fan deposits that evolved into stream channel/fluvial deposits. Sandstones are in an advanced to late diagenetic stage that is characterized by moderate to strong compaction (point-to-long grain contacts) and cementation by calcite, other clays, chlorite and opaque minerals, especially the strong alteration of feldspar grains into calcite and clay minerals. In addition, there are large amounts of clay minerals that play a role as detrital matrix-fill in pore spaces that reduce the reservoir quality of the rock; therefore, the visible porosity has been poorly evaluated.

In the TC-1 well, based on the results of petrography analyses at intervals of $850-1190 \mathrm{~m}$, the petrographic composition is calcareous-sandy shale, which are grey in colour, laminated and hard. They have been cut through by a calcite dyke (width 1.0-4.0 mm). The ditch cutting samples contain numerous pyrite crystals that are equally distributed within the rock and tend to increase at deeper burial depths (Truong and Nghia 1981).

\section{Biostratigraphic and petrographic characteristics of Paleogene sediments}

\section{Biostratigraphic characteristics}

The Paleogene sediments of the TC-2 well completely lack calcareous nannofossils and foraminifera, while the palynomorph assemblages are quite diverse and abundant compared to the underlying Cretaceous sediments. The presence of Bosedinia spp., Bosedinia kuantanensis, Pediastrum spp. and Pediastrum kajaites is characteristic of late Eocene-late Oligocene sediments belonging to a freshwater lacustrine environment that is commonly found in the Sunda shelf (Morley and Morley 2013), Malay basin (Yakzan et al. 
1996), West Java (Lelono 2012) and east of the Vietnam continental shelf (Cole 1992) (Figs. 11 and 12). This freshwater algal assemblage is very abundant in late Oligocene sediments in the Cuu Long basin (Dam and Quang 2015; Dam et al. 2017, 2018, 2019). In addition, the assemblages of Crassoretitriletes nanhaiensis, Magnastriatites howardi and Florschuetzia trilobata have a stratigraphic distribution range that is not older than the Oligocene age recorded in the Borneo area (Germeraad et al. 1968), and Lycopodiumsporites neogenicus is not younger than the late Oligocene age that is also found in this section (Hou 1981) (Fig. 12). In addition, the green algal taxa Botryococcus spp. and Botryococcus braunii, the freshwater spores Lygodiumsporites spp. and Polypodiaceaesporites undiff., and the freshwater pollen Merremia spp. and Palmae undiff. occur commonly and frequently in this sedimentary interval. Palynofacies 3 is characterized by the predominance of phytoclasts (over 97\%), which include palynomaceral 1 (avg. 70\%) and palynomaceral 2 (avg. 30\%) and no marine palynomorphs (Fig. 12). This palynofacies indicates that the sedimentary materials were deposited in freshwater lakes with relatively moderate energy settings.

For the TC-1 well, no characteristic fossils of the Paleogene period were found, and the sediments directly covering the Mesozoic basement were identified by Neogene sediments (Fig. 19). The palynology study results were recorded in the interval of 780-789 m and contain Rhizophora spp., Nothofagus spp., Myrica spp., Casurina spp., Ericipites spp., Tiliapollenites spp. and Lythocarpus spp. Notably, the presence of Florschuetzia levipoli appeared first in the early stage of the early Miocene and was common from the middle stage of the early Miocene to the late stage of the middle Miocene (Germeraad et al. 1968; Mao and Foong 2013). This is the basis for determining the interval of 780-789 m belonging to Miocene sediment and covering the Cretaceous sedimentary basement at $850 \mathrm{~m}$ in the sample (Fig. 19).

\section{Petrographic characteristics}

The petrographic analysis of Paleogene sediments was carried out on sidewall core samples in the TC-2 well. The petrographic composition is mostly feldspathic litharenite sandstone with minor sublitharenite. The grain size is medium to coarse $(0.25-1.0 \mathrm{~mm})$, it is moderately to well sorted, weakly to moderately compacted and displays point and floating types. The grain shape of detrital grains is mainly subangular, subrounded and rounded (Fig. 13).

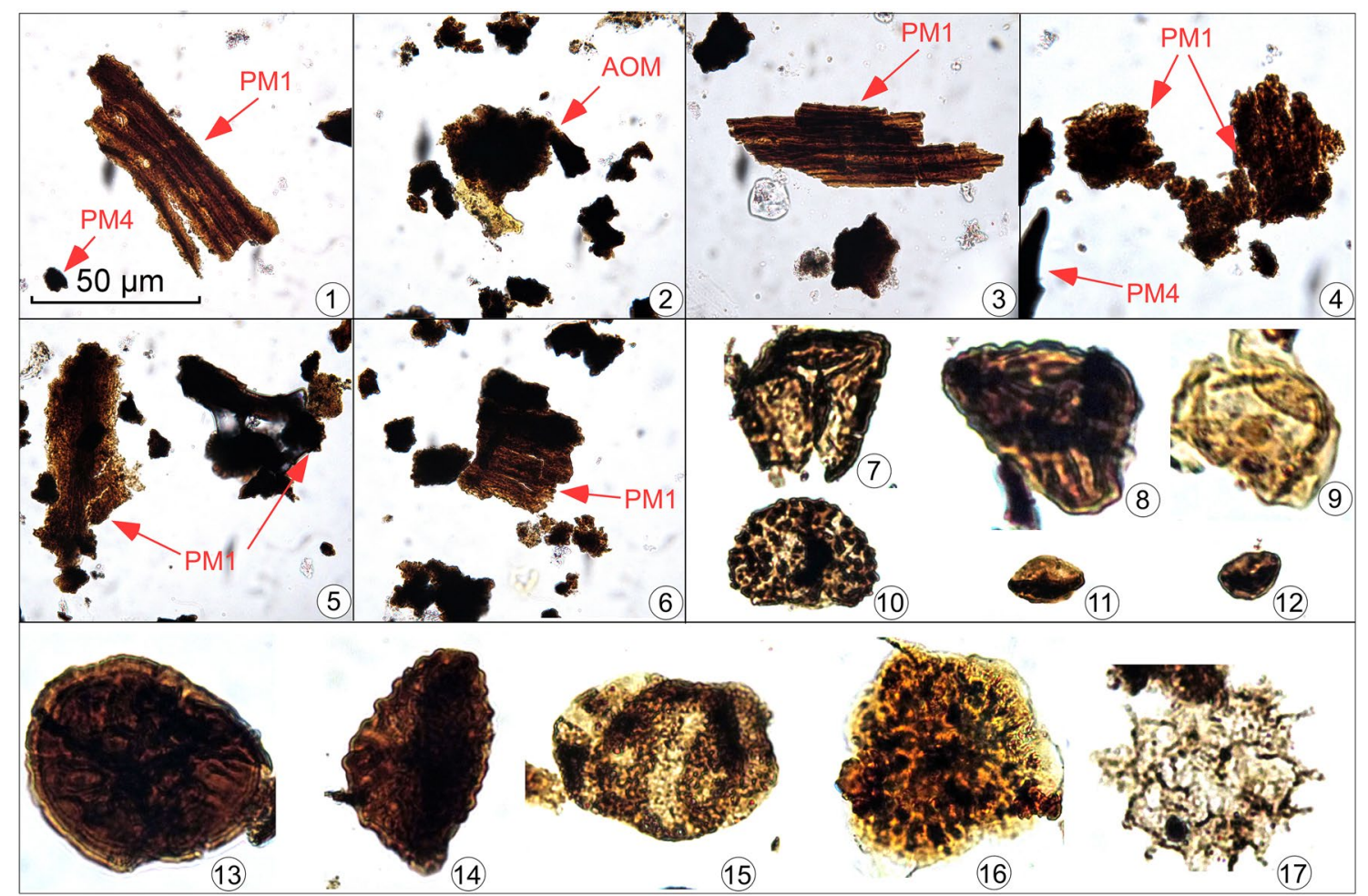

Fig. 12 1-6 Palynofacies dominated by palynomaceral type 1 (PM1) and sparse palynomaceral type 4 (PM4: opaque) in the TC-2 well. 7-17 Palynomorph assemblage of the Oligocene sediment in the TC-2 well. 7 Triletes sp., 8 Magnastriatites howardi, 9 Bosedinia kuantanensis, 10 Polypodiisporites perverrucatus, 11-12 Florschuetzia trilobata, 13 Lycopodiumsporites neogenicus, 14 Crassoretitriletes nanhaiensis, 15 Pinuspollenites sp., 16 Botryococcus braunii, 17 Pediastrum sp. Scale bar is $50 \mu \mathrm{m}$ 

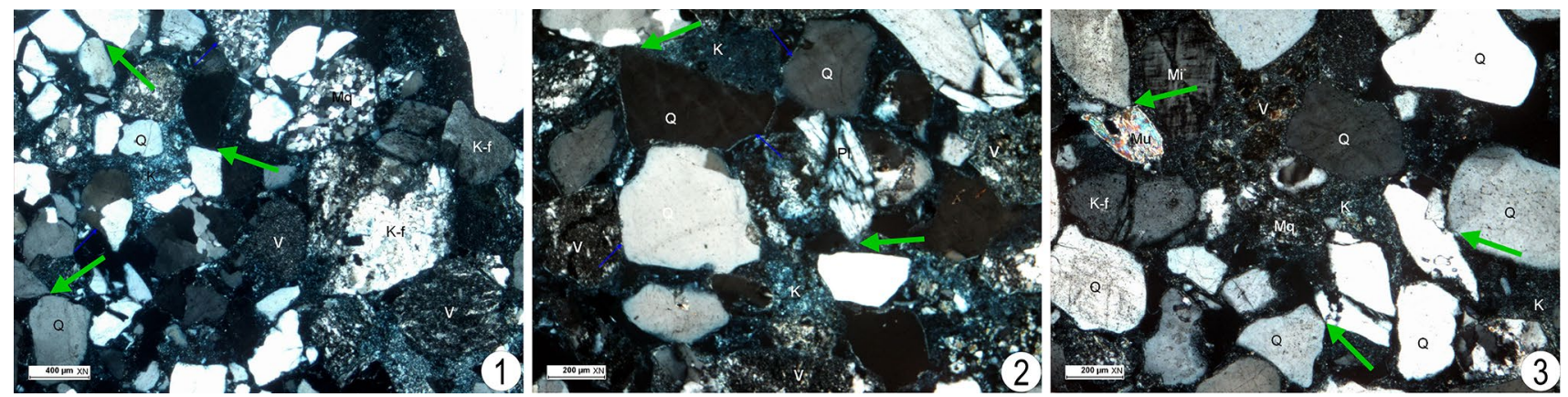

Fig. 13 Thin section photographs of the Oligocene sediment of the TC-2 well. 1 Depth of 994 m; 2 Depth of 1059.60 m; 3 Depth of $1071.50 \mathrm{~m}$. Feldspathic litharenite sandstone with mainly quartz (Q), $\mathrm{K}$-feldspar (K-f), microcline (Mi), plagioclase $(\mathrm{Pl})$ and mica $(\mathrm{Mu})$. There are many rock fragments, such as volcanic fragments $(\mathrm{V})$, chert

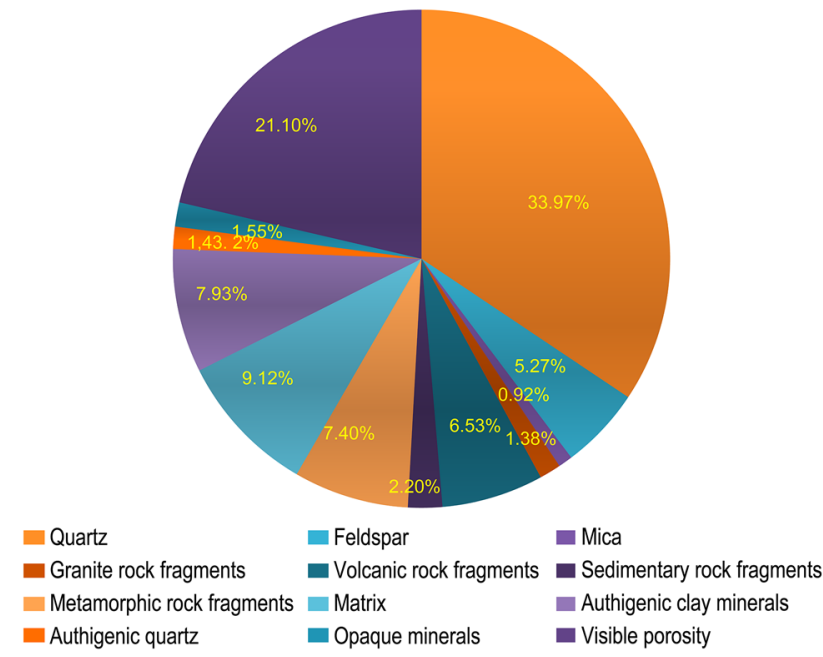

Fig. 14 Detrital grain composition (\%) of Oligocene sediments in the TC-2 well


(Ch), microquartz $(\mathrm{Mq})$, kaolinite $(\mathrm{K})$, siderite and opaque minerals (Op). They have medium grain size, good sorting, weak compaction with point-to-point grain contacts (green arrows) and mostly subrounded to rounded grain shapes

Detrital grains include predominantly quartz with mostly monocrystalline grains (18.4-43.2\%) and rarely polycrystalline grains. Feldspar is present in small amounts, such as $\mathrm{K}$-feldspar (2.6-5.2\%) and plagioclase $(0.2-1.8 \%)$, and local feldspar has been replaced by calcite or clay minerals. Mica appears at a low rate $(0.2-3.2 \%)$. Considerable other rock fragments, such as volcanic $(3.2-10.8 \%)$, granite (1.0-2.8\%), sedimentary (chert, carbonate) $(0.6-4.4 \%)$ and metamorphic fragments (schist, quartzite) $(0.8-9.4 \%)$ are present (Fig. 14). Accessory minerals include apatite, zircon, tourmaline and rutile in small amounts. A small amount of cement and authigenic minerals includes mainly kaolinite (3.4-6.4\%), siderite (trace-2.8\%), quartz overgrowths (1.0-2.0\%), other clay minerals $(2.0-4.8 \%)$ and opaque minerals (pyrite, haematite) (trace-3.8\%). Visible porosity has been evaluated very well, such as primary porosity (16.6-27.0\%), secondary porosity $(0.4-1.0 \%)$ and micropores within kaolinite patches (Fig. 15).

Scanning electron microscopy (SEM) analysis displays the morphology of authigenic minerals, secondary porosity, structure of the pore space and relationship between
Fig. 15 Thin section photographs of Oligocene sediment in the TC-2 well. 1 Depth of $1014 \mathrm{~m} ; 2$ Depth of $1.041 \mathrm{~m} ; 3$ Depth of $1071.50 \mathrm{~m}$. Primary pores (turquoise arrows) and dissolution of feldspar created intergranular pores (yellow arrows) filled with kaolinite (K), creating micropores (red arrows)

$\sqrt{1}$

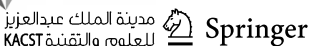


porosity and minerals. The main authigenic minerals recognized in SEM analysis include principally diagenetic clays such as illite, illite-smectite mixtures, kaolinite, chlorite, quartz overgrowths and pyrite. The pore system of most sandstones is very good. Quartz overgrowths (q) occur as euhedral quartz crystals that not only fill mostly intergranular pores but also block pore throats. Illite and illite-smectite (I/I-S) often occur as thin flakes, webbed or short fibres, or by filling pores and bridging pore throats. Smectite (S) shows a honeycomb assembly forming a thin coating on detrital grains. Kaolinite (K) crystals are present as blocky patches, completely filling intergranular pores and creating many micropores. Chlorite $(\mathrm{Ch})$ is present, as individual chlorite crystals are well oriented on edges with faces perpendicular to detrital grain surfaces that are completely coated on detrital grains. Feldspar (F) has been dissolved, creating much secondary porosity (Fig. 16). Therefore, the presence of clay minerals such as illite, illite-smectite and chlorite has significantly reduced the porosity and permeability of the rock. The kaolinite has partly reduced porosity and partly created micropores. In addition, the development of authigenic minerals such
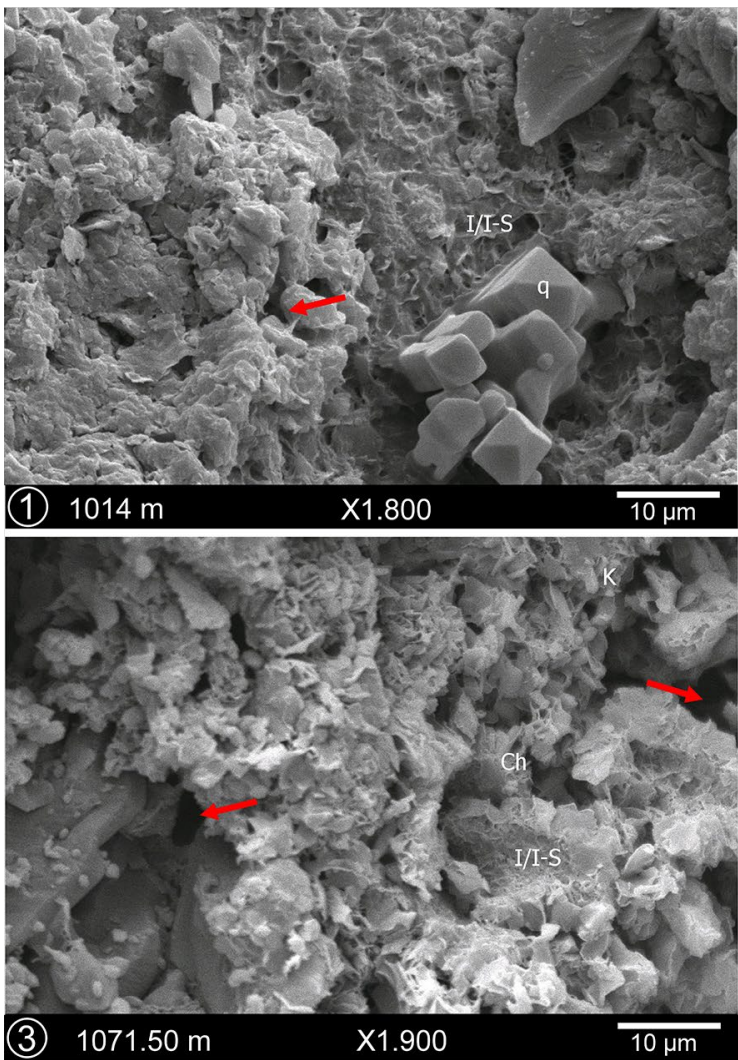

Fig. 16 SEM photograph showed the morphology of authigenic crystals and the porosity system in the TC- 2 well. 1 Quartz crystal (q) with a prismatic shape, illite and illite-smectite (I/I-S) appearing as thin flakes, webs and short fibres, with primary porosity indicated by red arrows; 2 smectite in a honeycomb form (S), with primary poros- as quartz overgrowths and pyrite also contributed to reducing the porosity of the rock.

The XRD analysis results also indicate that sandstones are quite clean and are mostly quartz with minor K-feldspar and clay minerals (Fig. 17). Clay minerals are present mainly as illite, kaolinite, chlorite and mixed-layer clay minerals of illite-smectite and smectite (Fig. 18). The increase in temperature with burial depth affected the alteration of clay minerals, the transformation of smectite into illite-smectite, smectite into chlorite and the appearance of illitization of flake/plate-shaped clay authigenic minerals.

Generally, the sandstones are in the early diagenetic stages and are characterized as weakly compacted (point-grain contacts and floating types) and cemented (kaolinite, siderite and quartz overgrowths). The partial dissolution and replacement of feldspar grains by kaolinite and other clay minerals such as illite, smectite and illite-smectite are present. Based on the petrographic composition (feldspathic litharenite and sublitharenite sandstone), framework grains and rock textures (medium to coarse grain size, moderate to well sorting, subangular and subrounded to rounded), less detrital matrix reveals
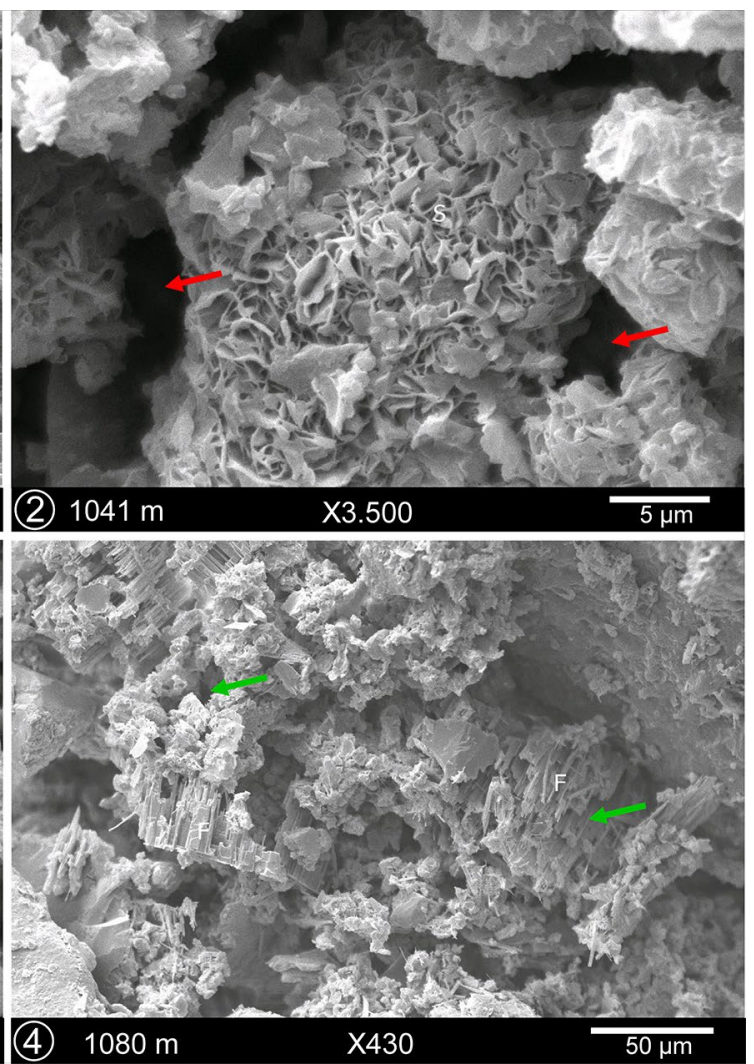

ity indicated by red arrows; 3 kaolinite formed as patches of crystals $(\mathrm{K})$; chlorite in thin flakes $(\mathrm{Ch})$, with primary porosity indicated by red arrows; 4 dissolved feldspar (F) creating secondary porosity (green arrows)

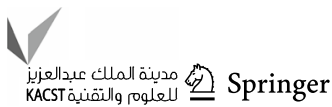




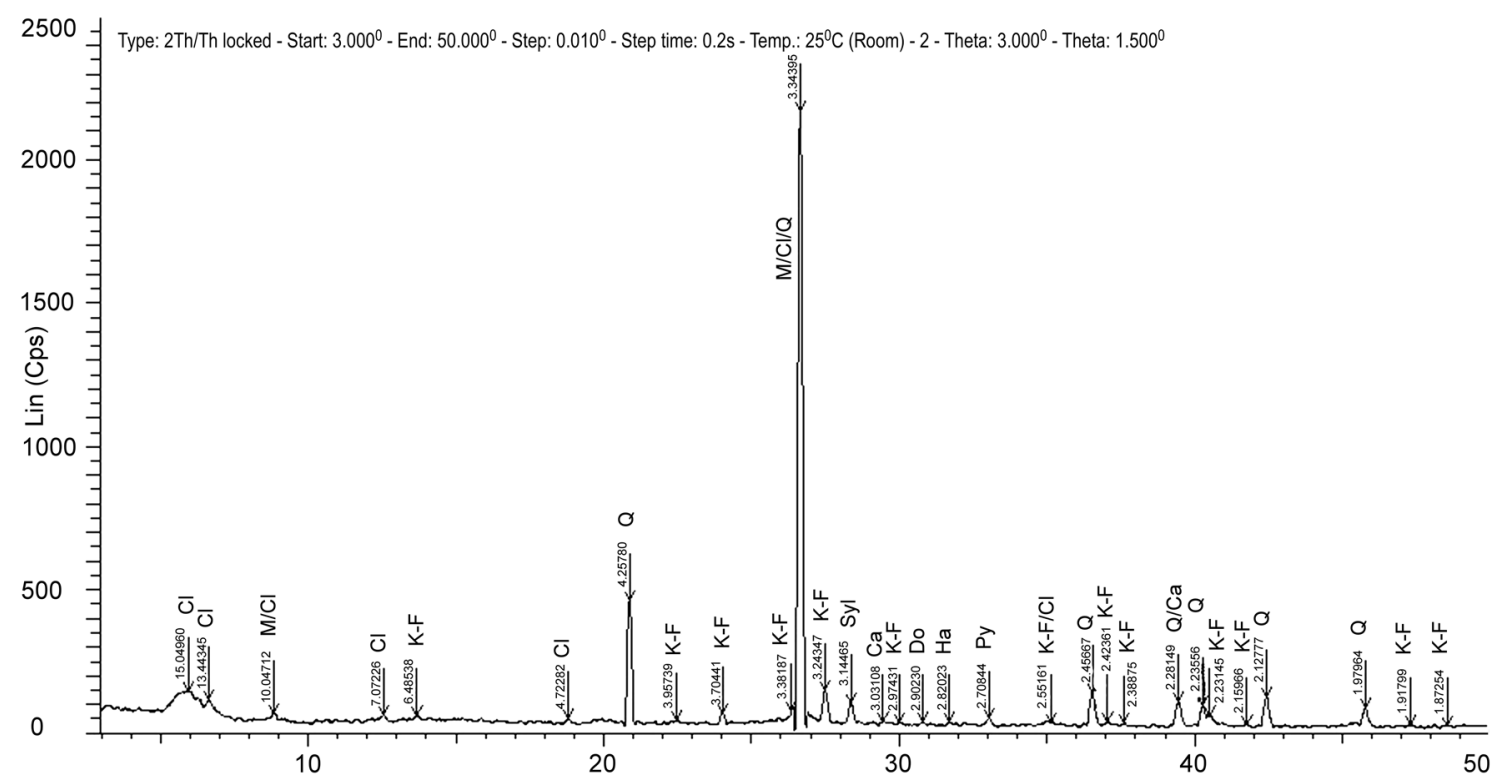

Fig. 17 XRD whole-rock analysis results at a depth of $1055 \mathrm{~m}$ in the TC-2 well



Fig. 18 XRD analysis results for the clay fraction at a depth of $1080 \mathrm{~m}$ in the TC-2 well

that sandstone is mature in terms of texture and minerals. These results predict that the rock-forming sediments were transported at a distance that was not far from their original areas, and sands may have been frequently subjected to high-energy flows and deposited in fluvial deposits. The visible porosity of most samples at this interval is good to extremely good, with mostly intergranular pores (16.6-27.0\%), secondary porosity within leached pores $(0.4-1.0 \%)$ and micropores within kaolinite.

\section{Discussion}

In the studied section of the TC-1 well, according to previous research results of Huy (1981) in the interval of 790-1190 m, fossils of palynomorphs and organic matter relics were not found. Therefore, the age of this section has not been determined. On the material basis of seismic, geophysical and petrographic descriptions, they predicted that this section is the pre-Cenozoic sedimentary 


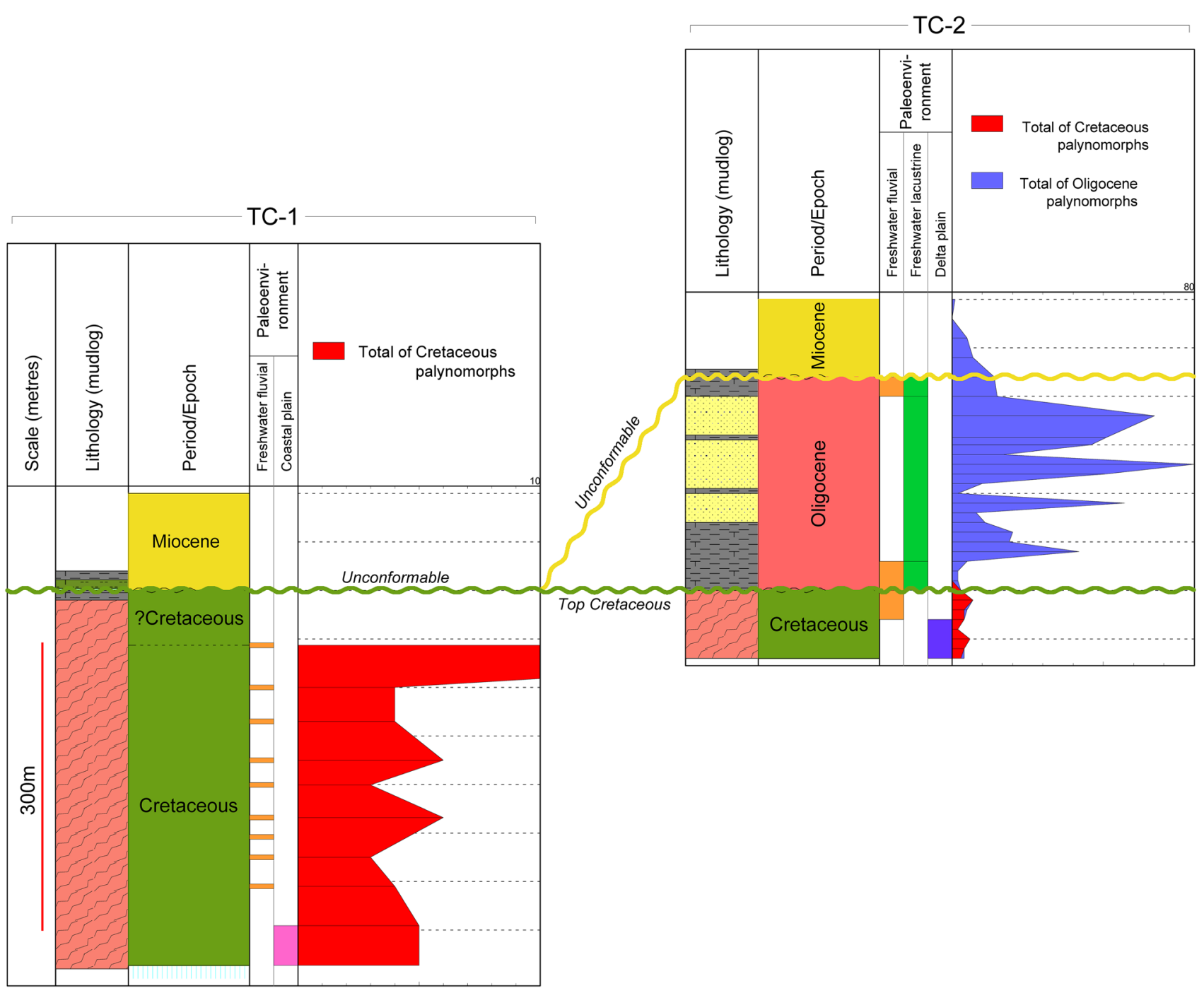

Fig. 19 Stratigraphic correlation of Cretaceous-Paleogene sediments between the TC-1 and TC-2 wells

basement. In recent years, oil and gas companies have researched and re-evaluated petroleum prospects in the inland part of the Cuu Long delta trough, so we have analysed in detail the stratigraphy of the TC- 1 well. The studied results revealed palynomorph assemblages of the Cretaceous period in 10 core samples from the interval of 857-1187 m. Furthermore, this palynomorph assemblage has also been found in the TC-2 well in the interval $1150-1220 \mathrm{~m}$. This is also a new discovery in this paper.

On the basis of a comparison of palynological assemblages, palynofacies characteristics and depositional environment shows that the sedimentary basement rock of the two TC-1 and TC-2 wells was deposited in the Cretaceous period and was dominated by continental sediments (Fig. 19). In addition, this fossil assemblage was also found in some studies on Phu Quoc Island and in the town of $\mathrm{Ha}$ Tien, which are located on the western margin of the Cuu
Long delta, and its stratigraphic distribution range from the Jurassic to Cretaceous period was determined by palynologists at the Vietnam Petroleum Institute and the PT Corelab Indonesia (Wantoro et al. 2005; Quang 2005, 2006). The northeastern margin of the Cuu Long delta is the Cuu Long basin, and the present study area does not contain Mesozoic sedimentary basement rock. Most of the basement rock in the Cuu Long basin is magmatic rock equivalent to the Hon Khoai, Dinh Quan and Ankroet complexes (Hiep and Dac 2018).

The Cretaceous-Paleogene boundary of the TC-1 well at a depth of $800 \mathrm{~m}$ was identified by the results of paleontological analysis, petrographic description and geophysical interpretation. For paleontology, in the interval of 780-789 m, Florschuetzia levipoli pollen was the first to appear in the early Neogene period. The core sample at $857.00 \mathrm{~m}$ contains abundant spores and pollen fossils that 
are characteristic of the Cretaceous period. For petrography, according to the results of Huy (1981) in the interval depth of 798-800 m, claystone has a disturbed form, unclear cross-bedding, crumpling and strong folds and contains reddish-brown iron oxide. This may be the weathering layer of the underlying rock formations. From an interval depth of 800-1190 m, the lithological characteristics are carbonate-silicate schist with a laminar layer and a blackish-green colour. For geophysics, the shape of the resistivity curves reflects the uniformity of the sedimentary formations from a depth of $800 \mathrm{~m}$ downwards. Therefore, a surface at a depth of $800 \mathrm{~m}$ can be considered an unconformity, which is the boundary between the Cretaceous and Paleogene sediments (Fig. 19).
Paleogene sediment is completely absent in the TC- 1 well and is relatively thin (approximately $220 \mathrm{~m}$ ) in the TC-2 well, but it is quite thick (over $3000 \mathrm{~m}$ ) in the central area of the Cuu Long basin (Dam 2017; Dam et al. 2018; Hiep and Dac 2018); thus, the thickness of Paleogene sediments tends to be bevelled and thinner from the continental shelf towards the mainland (Fig. 20). This finding may indicate that the strong tectonic activities in the late Mesozoic-early Cenozoic eras caused the topography of the basement rock in the study area to be uplifted and possibly eroded or disrupted by sedimentary formations during the Paleogene period. Currently, early-middle Paleogene sedimentary formations (Paleocene, Eocene) have not been found in the Cuu Long basin because all wells drilled through the basement have

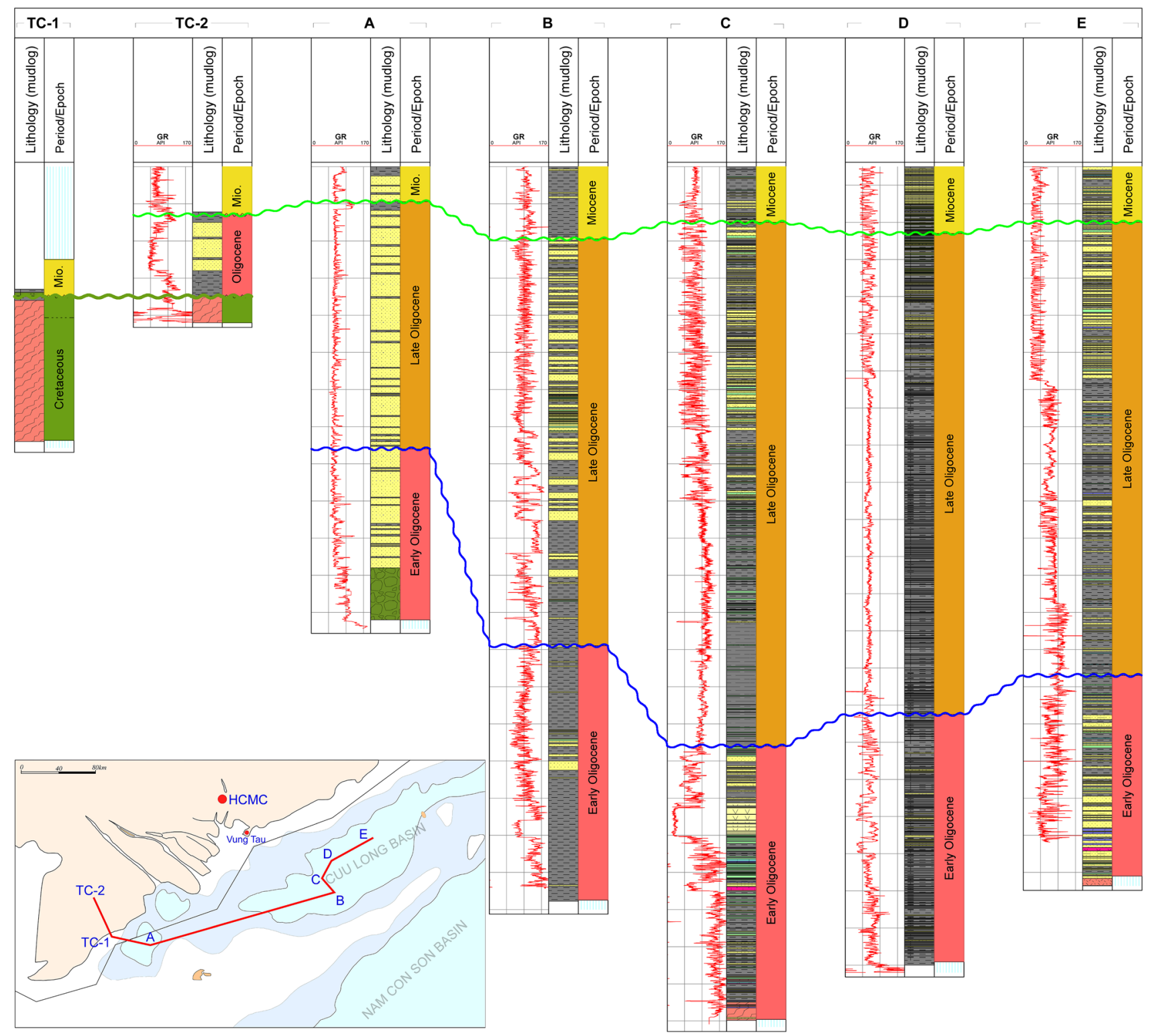

Fig. 20 Stratigraphic correlation between the studied wells and other wells in the Cuu Long basin 
only discovered Oligocene or younger sediments directly covering the basement rock, which are magmatic rock complexes of the pre-Cenozoic era. However, there are still more questions about sediments older than the Oligocene that exist in deep troughs of the Cuu Long basin (Northeast and East Bach Ho troughs) that cannot be answered without a well. Therefore, it is hypothesized that the entire Cuu Long delta region was uplifted during the early-middle Paleogene. Then, the eastern margin of the Cuu Long delta began the process of extension and subsidence (synrift period) to form the Cuu Long basin and adjacent basins, while the central Cuu Long delta, where the TC-1 well was located, continued to be uplifted and eroded until the end of the Paleogene, and the sediments were deposited in the early Neogene (lower Miocene).

At the end of the early Miocene, the entire eastern margin of the Cuu Long delta was submerged below sea level and covered with marine clay, which contains abundant fossils of the Rotalia genus and is widely distributed throughout the Cuu Long basin. In addition, the sedimentary formations directly covering the Mesozoic basement rock at the TC-1 well are the middle Miocene, which contains foraminifera fossils, indicating that the study area has marine intrusions and began to receive sediment from the Cuu Long delta plain trough.

Research samples are very well preserved with clear information and good quality. They are carried out synchronously for each analysis method. Moreover, the seismic and geophysical documents are also referenced to support the result interpretation for this study. Besides the advantages, this study also has some disadvantages and limitations as follows: (1) The geological data of the study area are relatively poor because the number of wells and samples is limited so the results of the study may not be representative for the entire Cuu Long delta. In addition, the spacing between the analysis samples is also quite wide. (2) Data collection of previous studies and analysis samples takes a long time because they are stored in many different libraries.

\section{Summary and Conclusions}

This study is one of the few studies which provide the data on geological development history and complete the stratigraphic column and evaluate the reservoir quality of study area. Several important conclusions can be drawn from the work:

- The sedimentary basement rock of the study area formed during the Cretaceous period and contains characteristic palynomorph assemblages that were found in several sections on the western margin of the Cuu Long delta. This palynomorph assemblage is very significant for studying and correlating the stratigraphy of the Cretaceous period in the southern Vietnam region.

- The palynofacies composition of the Cretaceous basement rocks is mainly phytoclast debris, which is dominantly palynomaceral types 1,2 and 4 , indicating that sedimentary materials are deposited mainly in freshwater fluvial environments with high-energy conditions.

- Arkosic sandstone is in the advanced to late diagenetic stage, and its visible porosity is estimated to be poor and has not been found in the Cuu Long basin.

- Paleogene sediment is deposited with a thickness of $220 \mathrm{~m}$ in the TC-2 well and is mainly felspathic litharenite sandstone; it directly covers Cretaceous sedimentary basement rock and contains the terrestrial palynomorph assemblage that represents the Oligocene period.

- Its palynofacies include palynomaceral types 1 and 2, suggesting that sedimentary materials were deposited mainly in freshwater lacustrine environments with high-energy conditions.

- Sandstone is at intermediate diagenetic stages, and the visible porosity is very well estimated. In the TC-1 well, which is uplifted or eroded, Paleogene sediment does not exist, but the Neogene sediment directly overlays the Cretaceous basement rock.

Acknowledgements The authors greatly appreciate the valuable comments and suggestions made by Dr. Lieu Kim Phuong, Vietnam Academy of Science and Technology, and Dr. Nguyen Thi Thu Cuc, University of Natural Sciences, National University of Hanoi, which helped to improve this manuscript. The authors gratefully acknowledge the Vietnam Petroleum Institute (VPI) for permission to use their data and samples for this paper.

Authors' contribution All authors contributed to the study conception and design. Material preparation, data collection and analysis were performed by MHD, VTT, NTT and NTT. The first draft of the manuscript was written by MHD, and all authors commented on previous versions of the manuscript. MHD analyzed and interpreted the palynology and palynofacies data regarding the biostratigraphic characteristics, synthesized the results of both biostratigraphic and petrological data and was a major contributor in writing the manuscript. NTT analyzed and interpreted the thin section and made the petrological photograph plates regarding the petrological characteristic. VTT analyzed and interpreted the SEM and XRD samples regarding the petrological characteristics. NTT collected the sample data and analyzed the calcareous nannofossil and foraminifera and made the fossil photograph plates and reviewed the final manuscript. All authors read and approved the final manuscript.

Funding Not applicable.

\section{Compliance with ethical standards}

Conflict of interest The authors have no conflicts of interest to declare.

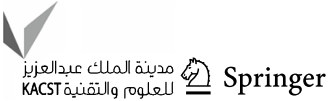


Open Access This article is licensed under a Creative Commons Attribution 4.0 International License, which permits use, sharing, adaptation, distribution and reproduction in any medium or format, as long as you give appropriate credit to the original author(s) and the source, provide a link to the Creative Commons licence, and indicate if changes were made. The images or other third party material in this article are included in the article's Creative Commons licence, unless indicated otherwise in a credit line to the material. If material is not included in the article's Creative Commons licence and your intended use is not permitted by statutory regulation or exceeds the permitted use, you will need to obtain permission directly from the copyright holder. To view a copy of this licence, visit http://creativecommons.org/licenses/by/4.0/.

\section{References}

Anderson JAR (1963) The flora of the Peat Swamp forests of Sarawak and Brunei, including a catalogue of all recorded species of flowering plants, ferns and fern allies. Gard Bull Singap 20(2):131-228

Anderson JAR (1964) The structure and development of the peat swamps of Sarawak and Brunei. J Trop Geogr 18:7-16

Anderson JAR, Muller J (1975) Palynological study of a holocene peat and a miocene coal deposit from NW Borneo. Rev Palaeobot Palynol 19:291-351. https://doi.org/10.1016/0034-6667(75) 90049-4

Backman J, Raffi I, Rio D, Fornaciari E, Pälike H (2012) Biozonation and biochronology of Miocene through Pleistocene calcareous nannofossils from low and middle latitudes. Newsl Stratigr 45:221-244. https://doi.org/10.1127/0078-0421/2012/0022

Batten DJ (1996) Palynofacies and petroleum potential. In: Jansonius J, McGregor DC (eds) Palynology: principles and applications. American Association of Stratigraphic Palynologists Foundation, Dallas, pp 1065-1084

Blow WH (1969) Late middle eocene to recent planktonic foraminiferal biostratigraphy. In: Bronnimann P, Renz HH (Eds.) Proceedings of the first international conference on planktonic microfossils ( $\mathrm{pp}$ 199-422) E.J. Brill, Geneva

Burger D (1996) Mesozoic palynomorphs from the North West Shelf, offshore Western Australia. Palynology 20:49-103. https://doi. org/10.1080/01916122.1996.9989470

Candel MS, Borromei AM, Martínez MA, Bujalesky G (2013) Palynofacies analysis of surface sediments from the Beagle Channel and its application as modern analogues for Holocene records of Tierra del Fuego, Argentina. Palynology 37:62-76. https://doi. org/10.1080/01916122.2012.718994

Cole JM (1992) Freshwater dinoflagellate cysts and acritarchs from Neogene and Oligocene sediments of the South China sea and adjacent areas. In: Head MJ, Wrenn JH (eds) Neogene and Quaternary dinoflagellate cysts and acritarchs. American Association of stratigraphic Palynologists Foundation, College Station, TX, pp 181-196

Copley A, Avouac JP, Royer JY (2010) India-Asia collision and the Cenozoic slowdown of the Indian plate: implications for the forces driving plate motions. J Geophys Res 115:B03410. https://doi.org/ 10.1029/2009jb006634

Crepet WL (1983) The role of insect pollination in the evolution of the angiosperms. In: Real L (ed) Pollination biology. Academic Press, Vienna, pp 29-50

Dam MH (2017) Updating and correcting the stratigraphic boundary of middle Miocene-Oligocene sediments in the Cuu Long basin. Vietnam Petroleum Institute, Hanoi

Dam MH, Quang CD (2015) Sequence stratigraphy and determining sedimentation environments ranged in age Early Miocene-Oligocene block 09-3 in Cuu Long basin based on characteristic of the freshwater dinocysts groups and palynofacies analysis. Petrovietnam $\mathbf{J}$ 7:24-32

Dam MH, Chung HN, Tham NT (2018) Characterisation of Oligocene palynomorphs in the Cuu Long basin and its stratigraphic significance. Petrovietnam J 4:23-36

Dam MH, Dung VT, Trieu NT, Duyen PT, Tuyen NT (2019) Biostratigraphic study and considerations for BH5.2 sequence in west Bach Bo trough Cuu Long basin. Petrovietnam J 1:41-49

Dao CV (2010) Completing the process of laboratory analysis of the Vietnam Petroleum Institute. Vietnam Petroleum Institute, Hanoi

Folk RL (1974) Petrology of sedimentary rocks. Hemphill Publishing, Texas

Folk RL, Ward WC (1957) A study in the significance of grain-size parameters. J Sediment Petrol 27:3-26. https://doi.org/10.1306/ 74D70646-2B21-11D7-8648000102C1865D

Fyhn MBW, Boldreel LO, Nielsen LH (2009) Geological development of the Central and South Vietnamese margin: implications for the establishment of the South China Sea, Indochinese escape tectonics and Cenozoic volcanism. Tectonophysics 478:184-214. https://doi.org/10.1016/j.tecto.2009.08.002

Germeraad JH, Hopping CA, Muller J (1968) Palynology of tertiary sediments from tropical areas. Rev Palaeobot Palynol 6:189-348. https://doi.org/10.1016/0034-6667(68)90051-1

Hardy RG, Tucker M (1988) X-ray powder diffraction of sediments. In: Tucker M (ed) Techniques in sedimentology. Blackwell Scientific Publications, Boston, pp 191-228

Helby R, Morgan R, Partridge AD (1987) A palynological zonation of the Australian Mesozoic. In: Jell PA (ed) Studies in Australian palynology. Association of Australasian Palaeontologists, Sydney, pp 1-94

Herngreen GFW, Chlonova AE (1981) Cretaceous microflora provinces. Pollen Spores 23:441-555

Hiep N, Dac NV (2018) Geology and petroleum resources of Vietnam. Science and Technology Publishing House, Hanoi

Hou YT (1981) Tertiary palaeontology of North continental shelf of South China Sea. BP Petroleum Development Ltd., Guangdong

Houghton HF (1980) Refined techniques for staining plagioclase and alkali feldspars in thin section. J Sediment Res 50:629-631. https://doi.org/10.1306/212f7a7c-2b24-11d7-8648000102c1865d

Huy NS (1981) Geological synthesis report of wells TC-2. General Department of Petroleum, Hanoi

Lelono EB (2012) Oligocene palynology of on-shore west Java. Sci Contrib Oil Gas 35:67-82

Mai NN (2016) Tracheophyta. In: Thanh TD, Nhuan MT, Nghi T (eds) Encyclopedia of geology. Hanoi National University Publishing House, Hanoi, pp 855-894

Mao L, Foong SY (2013) Tracing ancestral biogeography of Sonneratia based on fossil pollen and their probable modern analogues. Palaeoworld 22:133-143. https://doi.org/10.1016/j.palwor.2013. 09.002

Martini E (1971) Standard tertiary and quaternary calcareous nannoplankton zonation. In: Farinacci A (Ed) Proceedings of the second Planktonic conference, (pp 739-785) Edizioni Tecnoscienza, Roma

Morley RJ (1977) Palynology of tertiary and quaternary sediments in Southeast Asia. Proc Indones Pet Assoc 1:255-276. https://doi. org/10.29118/IPA.1896.255.276

Morley RJ (1991) Tertiary stratigraphic palynology in Southeast Asia: current status and new directions. Bull Geol Soc Malays 28(1):36. https://doi.org/10.7186/bgsm28199101

Morley RJ (2000) Origin and evolution of tropical rain forests. Wiley

Morley RJ, Morley HP (2013) Mid Cenozoic freshwater wetlands of the Sunda region. J Limnol 72:18-35. https://doi.org/10.4081/ jlimnol.2013.s2.e2 
Muller J (1968) Palynology of the Pedawan and Plateau sandstone formations (Cretaceous-Eocene) in Sarawak, Malaysia. Micropaleontology 14:1-37. https://doi.org/10.2307/1484763

Nielsen LH, Petersen HI, Thai ND, Duc NA, Fyhn MBW, Boldreel LO, Tuan HA, Lindström S, Hien LV (2007) A Middle-Upper Miocene fluvial-lacustrine rift sequence in theSong Ba Rift, Vietnam: an analogue to oil-prone, small-scale continental rift basins. Pet Geosci 13:145-168. https://doi.org/10.1144/1354-079307-748

Pellmyr O (1992) Evolution of insect pollination and angiosperm diversification. Trends Ecol Evol 7:46-49. https://doi.org/10.1016/ 0169-5347(92)90105-k

Peter AS, Spearing D (1982) Sandstone depositional environments. AAPG Memoir 31, Oklahoma

Vietnam Oil and Gas Group (2019) Map of Vietnam Oil and Gas activities, scale 1:2.300.000. Petroleum Archive Center, Hanoi

Pettijohn FJ (1975) Sedimentary rocks. Harper and Row Publishing House, New York

Phuong BTN (2010) Petrography, SEM and XRD analysis of DBSCL01-TSL report. Vietnam Petroleum Institute, Hanoi

Quang CD (2005) Biostratigraphic report outcrop samples in Phu Quoc, Ha Tien area. Vietnam Petroleum Institute, Hanoi

Quang CD (2006) Biostraitigraphic report of Enreca-2X well in Phu Quoc island. Vietnam Petroleum Institute, Hanoi

Solomon M, Green R (1966) A chart for designing modal analysis by point counting. Geol Rundsch 55:844-848. https://doi.org/10. 1007/bf02029658

Sykes H, Burnhill T, Trung PV, Chuong PV, Chi BMH (2011) Block DBSCL-01 evaluation report. Salamander Energy, Vietnam

Traverse A (2007) Differential sorting of palynomorphs into sediments: palynofacies, palynodebris, discordant palynomorphs. In: Traverse A (ed) Paleopalynology. Springer, Netherlands, Dordrecht, pp 543-579

Truong LV, Nghia NH (1981) Geological synthesis report of wells CL-1. General Department of Petroleum, Hanoi

Tyson RV (1984) Palynofacies investigation of Callovian (Middle Jurassic) Sediments from DSDP Site 534, Blake-Bahama Basin, western Central Atlantic. Mar Pet Geol 1:3-13. https://doi.org/10. 1016/0264-8172(84)90116-8

Tyson RV (1987) The genesis and palynofacies characteristics of marine petroleum source rocks. In: Brooks J, Fleet AJ (eds) Marine petroleum source rocks. Geological Society, London, pp 47-67. https://doi.org/10.1144/GSL.SP.1987.026.01.03
Tyson RV (1989) Late Jurassic palynofacies trends, Piper and Kimmeridge Clay Formations UK onshore and offshore. In: Batten DJ, Keen MC (eds) Northwest European micropalaeontology and palynology. British micropalaeontological society series, Chichester, pp 135-172. https://doi.org/10.1002/gj.3350260211

Tyson RV (1993) Palynofacies analysis. In: Jenkins DG (ed) Applied micropalaeontology. Springer Science Business Media, UK, pp 153-191. https://doi.org/10.1007/978-94-017-0763-3

Tyson RV (1995) Sedimentary organic matter: organic facies and palynofacies analysis. Chapman and Hall, London

Van der Zwan CJ (1990) Palynostratigraphy and palynofacies reconstruction of the Upper Jurassic to lowermost Cretaceous of the Draugen Field, offshore Mid Norway. Rev Palaeobot Palynol 62:157-186. https://doi.org/10.1016/0034-6667(90)90021-a

Van der Plas L, Tobi AC (1965) A chart for judging the reliability of point counting results. Am J Sci 263:87-90. https://doi.org/10. 2475/ajs.263.1.87

Wade BS, Pearson PN, Berggren WA, Pälike H (2011) Review and revision of Cenozoic tropical planktonic foraminiferal biostratigraphy and calibration to the geomagnetic polarity and astronomical time scale. Earth Sci Rev 104:111-142. https://doi.org/10. 1016/j.earscirev.2010.09.003

Wantoro HS, Richard H (2005) Biostratigraphy and paleoenvironments of 29 outcrop samples labelled "PN" from Phu Quoc-Ha Tien. Southwest Vietnam, Petrovietnam, Hanoi

Welton JE (2003) SEM petrology atlas. The American Association of Petroleum Geologists, Oklahoma

Whitaker MF (1984) The usage of palynostratigraphy and palynofacies in definition of Troll field geology. In: Reduction of uncertainties by innovative reservoir Geo-modelling. Offshore Northern Seas conference, Stavanger, Norway, 21 August 1984, pp 1-51

Yakzan AM, Harun A, Nasib BM, Morley RJ (1996) Integrated biostratigraphic zonation for the Malay Basin. Geol Soc Malays 39:157-184. https://doi.org/10.7186/bgsm39199615

Publisher's Note Springer Nature remains neutral with regard to jurisdictional claims in published maps and institutional affiliations. 